Outros Tempos, vol. 19, n. 33, 2022, p. 193-229. ISSN: 1808-8031

\title{
DOI: http://dx.doi.org/10.18817/ot.v19i33.914
}

JOÃO SOARES LISBOA CONTRA A BONIFÁCIA: a experiência hispano-americana durante o exílio contra o "Despotismo Togal" 1

JOÃO SOARES LISBOA AGAINST BONIFÁCIA: the hispano-american experience during exile against "Black Robe Despotism"

JOÃO SOARES LISBOA CONTRA A BONIFÁCIA: la experiencia hispano-americana durante el exilio contra el "Despotismo Togal"

\author{
PAULA BOTAFOGO CARICCHIO FERREIRA \\ ORCID: http://orcid.org/0000-0003-3196-3021 \\ Doutora em História pela Unicamp \\ paula.botafogo@gmail.com
}

\begin{abstract}
Resumo: O artigo trata da noção de justiça de João Soares Lisboa nas edições do Correio do Rio de Janeiro de 1823 que foram redigidas da prisão, depois que seu redator retornou do exílio em Buenos Aires e era acusado de "conluio republicano". Essas publicações são analisadas à luz do exílio como um mecanismo da política liberal, da definição de João Paulo Pimenta de "experiência hispanoamericana" e das categorias de "espaço de experiência" e "horizonte de expectativa" de R. Koselleck. Soares Lisboa defendia a vigilância dos cidadãos aos magistrados, assegurando uma justiça cidadã contra o "Despotismo Togal", associada à virtude, moral e mérito. Esta concepção contribuiu para que as publicações do Correio do Rio de Janeiro fossem lidas como radicais e republicanas pelos seus coevos e seu redator como coadjuvante na independência do Brasil, agindo à sombra de Joaquim Gonçalves Ledo, visão que se perpetuou na historiografia.
\end{abstract}

Palavras-chave: Independência do Brasil. Justiça. Imprensa.

\begin{abstract}
The article is about João Soares Lisboa's notion of justice in the Correio do Rio de Janeiro editions of 1823 that were written during his imprisonment, after its editor returned from exile in Buenos Aires and was accused of "republican collusion". These publications are analyzed in the light of exile as a mechanism of liberal politics, of João Paulo Pimenta's definition of "Hispanic-American experience", and of R. Koselleck's "experience space" and "expectation horizon" categories. Soares Lisboa defended the vigilance of citizens to magistrates, ensuring citizen justice against "Black Robe Despotism", associated with virtue, morals, and merit. This concept contributed to the Correio do Rio de Janeiro's publications being read as radical and republican by their contemporaries, and its editor being seen as a supporting role in the independence of Brazil, acting in the shadows of Joaquim Gonçalves Ledo, a vision that has been perpetuated in historiography.
\end{abstract}

Keywords: Independence of Brazil. Justice. Press.

Resumen: El artículo trata sobre la noción de justicia de João Soares Lisboa en las ediciones de 1823 del Correio do Rio de Janeiro que fueron redactadas desde la cárcel, luego de que su editor regresara del exilio en Buenos Aires y fuera un caso de "colusión republicana". Estas publicaciones se analizan a la luz del exilio como mecanismo de la política liberal, la definición de João Paulo Pimenta de la "experiencia hispanoamericana" y las categorías de "espacio de experiencia" y "horizonte de expectativas" de R. Koselleck. Soares Lisboa defendió la vigilancia de la ciudadanía ante los magistrados, asegurando la justicia ciudadana frente al "Despotismo Togal", asociado a la virtud, la moral y el mérito. Este concepto contribuyó a que las publicaciones del Correio do Rio de Janeiro

\footnotetext{
${ }^{1}$ Artigo submetido à avaliação em agosto de 2021 e aprovado para publicação em dezembro de 2021.
} 
Outros Tempos, vol. 19, n. 33, 2022, p. 193-229. ISSN: 1808-8031

fueran leídas como radicales y republicanas por sus contemporáneos y su editor como apoyo a la actuación en la independencia de Brasil, a la sombra de Joaquim Gonçalves Ledo, visión que se ha perpetuado en la historiografía.

Palabras clave: Independencia de Brasil. Justicia. Prensa.

Em fevereiro de 1823, a embarcação inglesa Charles, vinda de Buenos Aires, aportou no Rio de Janeiro transportando dentre seus passageiros João Soares Lisboa ${ }^{2}$. Logo que sua chegada foi noticiada, ele foi encarcerado para responder na prisão à bonifácia. Este foi o nome dado à devassa aberta, em 1822, pela historiografia. O ministro José Bonifácio de Andrada acusava uma série de liberais, como Joaquim Gonçalves Ledo, Januário da Cunha Barbosa e Clemente Pereira, de "conluio republicano" contra o governo monárquico de D. Pedro (FERREIRA, 2017; SCHIAVINATTO; FERREIRA, 2014a; VARNHAGEN, 2010, p. 230). Do cárcere, Soares Lisboa voltou a publicar o jornal Correio do Rio de Janeiro, infringindo a ordem de sua paralisação no ano anterior determinada pela devassa da bonifácia, quando também foi intimado pelo governo a deixar o Brasil, exilando-se em Buenos Aires (1822-1823) (FERREIRA, 2021a).

Em 1822, João Soares Lisboa era uma figura conhecida na Corte pela redação do Correio do Rio de Janeiro, único periódico de tiragem diária a se rivalizar com a Gazeta do Rio de Janeiro, que protagonizou a narrativa sobre a Independência até sua morte em luta pela Confederação do Equador, no Couro D’Anta, em 1824 (FERREIRA, 2014, 2017; LEITE, 2000). Em 1800, veio do Minho ainda jovem para Porto Alegre e progrediu no trato mercantil, associando seus negócios ao transporte de produtos gaúchos para a Bahia e abastecimento das tropas portuguesas no extremo-sul e Montevidéu, expandido para a Corte. Em 1818, João Soares Lisboa consolidou seus negócios, matriculando-se como negociante de grosso trato (FERREIRA, 2020b).

É notória a participação de Soares Lisboa no debate sobre a construção do Estado e da nação do Brasil por intermédio da redação do Correio do Rio de Janeiro. Basta dizer que divulgou e convocou o público a ratificar a Representação do Povo do Rio de Janeiro, documento que pedia a convocação de Cortes do Brasil ao príncipe regente D. Pedro, em maio de 1822. Na solicitação figuravam ainda Joaquim Gonçalves Ledo, José Clemente Pereira, Bernardo José da Gama e os padres Januário da Cunha Barbosa e Antônio João Lessa.

\footnotetext{
${ }^{2}$ Diário do Governo do Rio de Janeiro, n. 40, 19 fev. 1823. p. 164. Hemeroteca Digital da Biblioteca Nacional (Rio de Janeiro). Disponível em: http://bndigital.bn.gov.br/ Acesso em: 28 ago. 2021.
} 
Outros Tempos, vol. 19, n. 33, 2022, p. 193-229. ISSN: 1808-8031

A trajetória pública de João Soares Lisboa tornou-se objeto relevante à história, primeiro, em razão do protagonismo de suas publicações no processo de politização dos debates desse período; em segundo, por ter sido réu em processos judiciais movidos pela Corte, sobretudo, na bonifácia, quando, pela primeira vez no Brasil independente, se judicializava a questão da política. Antes disso, em julho de 1822, Soares Lisboa foi citado ao libelle civil, acusado de "crime de injúria atroz" por Joaquim Maria da Gama Freitas Berquó e Francisco Maria Gordilho de Barbuda, criados do príncipe regente D. Pedro ${ }^{3}$. No mês seguinte, Soares Lisboa foi o primeiro redator a ser indiciado por "abuso da liberdade de imprensa", julgado e absolvido por júri popular (FERREIRA, 2017, p. 187-206; LEITE, 2000; NEVES, 2003, p. 344-354; LUSTOSA, 2000, p. 174-181; RIZZINI, 1988, p. 397).

Lúcia Maria Bastos Pereira das Neves (2003) destaca o protagonismo de João Soares Lisboa no Correio do Rio de Janeiro, ao adotar "posturas mais radicais e democratas" baseadas na ideia de soberania popular. Ele seria "[...] um dos primeiros a defender a convocação de uma Assembleia Constituinte para o Brasil, porque era nesta que via a soberania da Nação". A defesa legitimava a convocação das Cortes para o Brasil, a Constituição e a eleição direta dos deputados à Assembleia do Brasil (NEVES, 2003, p. 45). João Soares Lisboa, apesar de português de nascimento, era um dos membros do "grupo brasiliense" ligado aos constitucionais Joaquim Gonçalves Ledo e padre Januário da Cunha Barbosa, redatores do Reverbero Constitucional Fluminense. Ainda interessa destacar que os três apresentavam conceito de Constituição fundado em princípios democráticos e oposto à concepção expressa pelos membros do "grupo coimbrão", como José da Silva Lisboa, futuro visconde de Cairu (NEVES, 2003).

As publicações do Reverbero Constitucional Fluminense, jornal de Joaquim Gonçalves Ledo e do padre Januário da Cunha Barbosa, representavam, na imprensa fluminense, os interesses de um grupo de "liberais" que articulava os proprietários de lavouras comerciais e os donos de engenhos do Recôncavo e de Goitacazes, aliados a comerciantes, negociantes atacadistas e burocratas. $\mathrm{O}$ grupo visava à elaboração de legislação que garantisse a formalização das mudanças ocorridas no mercado e a eliminação dos obstáculos à mercantilização da produção, da terra e da força de trabalho. Liderados por Joaquim Gonçalves Ledo, as publicações dos dois jornais, Revérbero e Diário, e o engajamento político dos "liberais" expressavam a "astúcia" do comerciante, articulando posicionamentos políticos conforme interesses mercantis (OLIVEIRA, 1999, p. 196).

\footnotetext{
${ }^{3}$ Correio do Rio de Janeiro, n. 62, 27 jul. 1822. p. 253. Hemeroteca Digital da Biblioteca Nacional (Rio de Janeiro). Disponível em: http://bndigital.bn.gov.br/ Acesso em: 28 ago. 2021.
} 
Outros Tempos, vol. 19, n. 33, 2022, p. 193-229. ISSN: 1808-8031

O Correio do Rio de Janeiro publicava que o príncipe regente era "puro democrata" e aclamou "Pedro $1^{\circ}$ sem $2^{\circ}$ ", o que, na época, se tornou bordão associado a João Soares Lisboa e característico de seu republicanismo. Renato Lopes Leite (LEITE, 2000, p. 49) vincula os princípios dos republicanos de 1822 e o republicanismo de 1824, concretizados na Confederação do Equador. Nesse sentido, existiram pelo menos dois projetos para o Brasil discutidos na imprensa do período. Um arquitetado pelos "absolutistas monárquicos" e outro fruto das ideias dos adeptos do "republicanismo". E João Soares Lisboa era o principal representante da "imprensa libertária republicana" e, por isso, foi denunciado pelos seus contemporâneos nos processos judiciais movidos pelo governo da Corte, e condenado na bonifácia (LEITE, 2000, p. 227-228).

Quando se considera o pensamento de João Soares Lisboa como o porta-voz do republicanismo, a data mais importante do processo de independência consistiria no episódio de convocação da Assembleia Constituinte e Legislativa do Brasil, de três de junho de 1822. Renato Lopes Leite conclui que a historiografia elevou o Fico e o Sete de Setembro como os fatos marcantes do processo de independência do Brasil, sustentando-se na escamoteação do(s) projeto(s) republicano(s). O episódio de três de junho de 1822, quando da convocação da Assembleia Constituinte e Legislativa do Brasil, constituiu-se na data de maior importância que revelaria "[...] o melhor exemplo do poder de fogo da imprensa republicana" (LEITE, 2000, p. 307-308).

Em 1823, a volta de João Soares Lisboa ao Brasil, após exílio imposto pela bonifácia, suscitou críticas. O correspondente, que assinava pelo codinome Admirado das coisas deste Mundo, enviou, ao Diário do Rio de Janeiro, carta indignada com o "atrevimento" do "mui ledo" Soares Lisboa, referindo-se à aliança com Joaquim Gonçalves Ledo, também exilado em Buenos Aires. Depois, o correspondente mencionava o El Argos de Buenos Aires, associando Soares Lisboa ao constitucionalismo elaborado pela elite portenha ilustrada, representada institucionalmente pelo ministro de governo, Bernardino Rivadavia ${ }^{4}$. A autoridade portenha era recorrentemente citada nos relatos sobre a experiência hispanoamericana de exílio de Soares Lisboa, sobretudo, nas descrições do cônsul do Brasil em Buenos Aires, Antônio Correia da Câmara (FERREIRA, 2017, p. 235-261).

O ministro Bernardino Rivadavia, apoiado pelos grupos mais poderosos de Buenos Aires formados por grandes comerciantes e proprietários ligados ao comércio de produtos pecuários, implementou institucionalmente projeto de reformismo ilustrado. Em

\footnotetext{
${ }^{4}$ Diário do Governo do Rio de Janeiro, n. 43, 22 fev. 1823. p. 176. Hemeroteca Digital da Biblioteca Nacional (Rio de Janeiro). Disponível em: http://bndigital.bn.gov.br/ Acesso em: 28 ago. 2021.
} 
Outros Tempos, vol. 19, n. 33, 2022, p. 193-229. ISSN: 1808-8031

clara tentativa de neutralizar conflitos políticos que desestabilizavam e paralisavam o governo, Bernardino Rivadavia defendia a instituição de cortes parlamentárias com o objetivo de institucionalizar as práticas de poder, transformando-as em espaço dominado pela razão e experiência deliberativa. No mesmo ano, o periódico El Argos de Buenos Aires começou a ser publicado, disseminando, por toda a era rivadaviana (1821-1824), o pensamento ilustrado da elite portenha e o seu discurso em torno da definição da nação rioplatense (MYERS, 2004; TERNAVASIO, 2009, p. 140)5 .

Soares Lisboa, Rivadavia e seus consignatários, além de compartilharem do ideário reformista, convergiam em seus interesses comerciais, dada a experiência no trato mercantil com militares, com negócios pecuários nas fronteiras do Rio Grande e no comércio de grosso trato do Rio de Janeiro. Antes de se retirar do Rio de Janeiro, em outubro de 1822, foi outorgada para João Soares Lisboa a procuração do Alferes Francisco Teles de Sousa, negociante de Entre Rios, no Vice-Reino do Rio da Prata, que lhe conferia poderes para comercializar em seu nome e justificava formalmente sua passagem do Brasil aos domínios hispano-americanos. As ligações de João da Silva Lisboa no exílio com impressores propiciaram a reimpressão do Correio do Rio de Janeiro em Montevidéu (FERREIRA, 2017, p. 226-252, 286-312; FERREIRA, 2021a).

Apesar de Soares Lisboa não mencionar diretamente os periódicos publicados em Buenos Aires e Montevidéu no Correio do Rio de Janeiro redigido da prisão, suas ideias se radicalizaram, aproximando-se de Cipriano Barata e frei Caneca e distanciando-se dos seus antigos aliados, a partir de um repertório de concepções, princípios e ideias semelhantes às registradas nesses jornais, patente na sua concepção de ampla participação cidadã no governo, inclusive, na defesa de uma justiça cidadã contra o poder dos "togados". Dentre outras formulações, a questão da regulamentação das liberdades dos cidadãos e as noções de virtude e justiça publicadas por Soares Lisboa são questões amplamente inspiradas em sua experiência hispano-americana ${ }^{6}$ no exílio em Buenos Aires. De acordo com Mario Sznajder e Luis Roniger, com os movimentos independentistas na América, o exílio se tornou um "mecanismo regulador" de sistemas políticos que eram inaugurados e "[...] incapaces de crear modelos de participación plurales e inclusivos" (RONIGER; SZNAJDER, 2014, 206). O exílio mantinha a estabilidade do governo, contribuindo para reorganizar e superar

\footnotetext{
${ }^{5}$ Com duas a três edições por semana, El Argos foi publicado em duas fases, de 12 de maio de 1821 até 24 de novembro de 1821 e de 19 de janeiro 1822 até 19 de outubro de 1825 . Teve diversos redatores ao longo de sua existência. Em sua primeira fase, Don Santiago Wilde e Don Ignacio Núñez assumiram essa função; na segunda, redatores ligados a Sociedade Literária de Buenos Aires (BELTRAN, 1943, p. 135-140; LESCANO, 2015).

${ }^{6}$ Definida por João Paulo Garrido Pimenta $(2015 ; 2017)$.
} 
Outros Tempos, vol. 19, n. 33, 2022, p. 193-229. ISSN: 1808-8031

dissidências políticas internas. Nos regimes de governo representativos e liberais, por meio do exílio se passou a lidar com a oposição de forma diferente do que havia sido feito no Antigo Regime: ela não era mais liquidada, mas se voltava para a negociação política, o que foi possível graças a um espaço público moderno de ampla circulação atlântica de informações e pessoas (KOSELLECK，1999，2006; MOREL，2005; RONIGER; SZNAJDER，2014; TOMICH, 2004).

Para quem era exilado, a experiência de exílio compreendia uma dimensão geográfica e outra temporal (RONIGER; SZNAJDER, 2014, 748). A primeira, mais evidente, era fruto do seu deslocamento. Os exilados participavam de redes de migrações políticas transfronteiriças e transoceânicas, que interconectavam amplos setores das elites políticas e intelectuais ibero-americanas. Para Javier Fernández Sebastián, estes atores em movimento foram capitais na politização e disseminação, em espaços singulares da Ibero-América, de conceitos políticos apropriados durante a primeira metade do século XIX (FERNÁNDEZ SEBASTIÁN, 2009, p. 696-699; p. 713-714). Por sua vez, a dimensão temporal do exílio se caracteriza pela mobilidade dos exilados entre marcos temporais, “[...] del pasado al presente y del presente al pasado, en sus remembranzas, nostalgia e imaginación, al tiempo que mantienen planes y expectativas para el futuro" (RONIGER; SZNAJDER, 2014). Neste sentido, o acúmulo de experiências políticas transformou suas expectativas sobre seus projetos políticos de futuro ${ }^{7}$. Ao formularem uma nova identidade, um ethos, os exilados necessariamente vivenciavam uma transformação em nível individual e coletivo e, nessa construção, compartilhavam e redefiniam noções políticas e culturais (RONIGER; SZNAJDER, 2014). Durante o fim do século XVIII e início do XIX, sobretudo em um momento de efervescência e profundas transformações políticas no bojo das recentes independências na América, o exílio propiciava novos olhares sobre o outro por meio de leituras e vivências que permitiam, em seu conjunto, alimentar visões de possibilidades políticas inovadoras.

Apesar de experiências históricas únicas, os diversos contextos na América colonial e recém-independente constituíam um só em suas percepções e concepções do tempo histórico, relativo a um fenômeno comum (PIMENTA, 2008, p. 58), que vislumbrou o espaço de experiência da América espanhola e dos novos países hispano-americanos como um alargamento do espaço de alternativas (PIMENTA, 2015, p. 30). Nesse sentido, tendo em vista a provisoriedade, incertezas e a aceleração do tempo histórico (JANCSÓ; PIMENTA,

\footnotetext{
${ }^{7}$ Cf. as categorias de espaço de experiência e horizontes de expectativas em KOSELLECK, 2006.
} 
Outros Tempos, vol. 19, n. 33, 2022, p. 193-229. ISSN: 1808-8031

2000), a trajetória de João Soares Lisboa, tal como um personagem atlântico, é exemplar do entroncamento entre uma rede de informações ampliada pela circulação de impressos de variadas naturezas e uma malha já estabelecida anteriormente de trocas comerciais e culturais, que era potencializada por demandas políticas advindas da crise, sendo propiciadora, segundo João Paulo Pimenta, de “[...] condições de possibilidade para a criação de um espaço político específico no qual se define a indissociabilidade de destinos entre a América portuguesa e a América espanhola.” (PIMENTA, 2015, p. 60). Esta indissociabilidade ou interdependência das revoluções atlânticas (FERNÁNDEZ SEBASTIÁN, 2009, p. 713) alimentava as expectativas sobre o liberalismo, a modernidade e a construção do Estado e da nação do Brasil, vislumbrando o exercício de um regime monárquico com base nos princípios de liberdade, virtude e cidadania pelo uso de conceitos reelaborados a partir da experiência hispano-americana.

Tal como concebido por R. Koselleck (2014, p. 36), entende-se que experiências são "singulares na medida em que ocorrem e são replicáveis na medida em que são acumuladas". Neste sentido, a experiência hispano-americana de João Soares Lisboa se reflete na história da independência e construção do Estado e da nação do Brasil em seu duplo aspecto: "aquele constituído pela experiência e aquele que pode ser derivado dela". Ao analisarmos os estratos do tempo que a constituem, podemos visualizar o que há de singular e surpreendente em sua trajetória, bem como as experiências acumuladas que estruturaram suas vivências e apropriações.

Deste modo, são pertinentes as acepções que tiveram tamanho impacto no modo do redator de imaginar o exercício do governo liberal e que transformaram ou reelaboraram suas convicções, sentidos e representações sobre a monarquia constitucional e a república em sua produção textual e trajetória pública durante os anos de 1823 e 24. Assim, a partir da análise da experiência hispano-americana do exílio de Soares Lisboa, pode-se dizer que em sua produção textual pública ele se apropriava de conceitos políticos que, desenvolvidos e discutidos em termos republicanos em Buenos Aires, foram por Soares Lisboa e outros liberais do período imaginados em uma monarquia constitucional no Império do Brasil. Dessa maneira, Soares Lisboa discutia e se posicionava sobre os dilemas para concretizar um governo estável, baseado na liberdade e com ampla participação popular, vivido, sobretudo, durante a construção do Império do Brasil no Período Regencial (BASILE, 2004; MOREL, 2005; 2017).

A convicção sobre o dever dos cidadãos em um governo representativo - no caso, republicano - de vigiarem o poder, sobretudo dos magistrados para não incorrerem em 
Outros Tempos, vol. 19, n. 33, 2022, p. 193-229. ISSN: 1808-8031

arbitrariedades contra os cidadãos e ingerência em outros poderes, era generalizada nos periódicos publicados em Buenos Aires e Montevidéu nos primeiros anos da década de 1820 (FERREIRA, 2021b; DEMURO, 2018; WINTER, 2018) ${ }^{8}$. De forma exemplar, no periódico El Espiritu de Buenos Aires, seu redator apresentava sua concepção de justiça, contrapondo que seria útil, honroso e virtuoso nos governos monárquico e republicano. No primeiro caso, o útil era o justo e produzia honra; nos republicanos, o justo era o útil e a honra produzia a virtude, por isso, “[...] es preciso que al Espíritu le ocupe la virtud”. Conclusão: "El gobierno monárquico se aproxima más al despótico en el republicano, tendendo a vícios e virtudes medíocres" ". Para o redator, nas repúblicas, pelo contrário, tudo era sublime. No limite, a base da república era a virtude, sendo de "absoluta necesidad" que os cidadãos fossem virtuosos, pois disso dependia a estabilidade do governo: “[...] El premio al mérito y a la virtud sea cual. Sea la clase del ciudadano que lo contraiga o ejerza es el elemento de todo el bien.”. Desta maneira, de acordo com o redator, “[...] el vicio será perseguido y la virtud justamente exaltada" $" 10$.

Ao que interessa a essa análise, na concepção apresentada nesse periódico, a justiça integraria a moral e o que era moral, por conseguinte, far-se-ia justo. A justiça era definida pela lei, com base no bem público: "Por consecuencia el que deja de hacer lo justo comete una injusticia. Viola la ley. Destruye la garantía social, y en todo obra contra el interés público. He aquí las consecuencias naturales que emanan de aquel elemento ruinoso" "A partir da definição de justo, opera-se uma transformação profunda na concepção do lugar da

\footnotetext{
${ }^{8}$ Os periódicos investigados integraram a pesquisa de pós-doutorado em andamento e financiada pela FAPESP (2019-2022) no departamento de História da Universidade de São Paulo (USP). Por exemplo, Cf. El Teatro de la Opinión, n. 8, 11 jul. 1823; Legión del Orden ó Voz del Pueblo, n. 10, 12 jan. 1821 Disponível em: https://catalogo.bn.gov.ar Acesso em: 28 ago. 2021; El Espíritu de Buenos Aires, n. 4, 6 fev. 1822. Colecciones Digitales. Biblioteca Nacional Mariano Moreno (Buenos Aires). Disponível em: https://catalogo.bn.gov.ar Acesso em: 28 ago. 2021; El Espíritu de Buenos Aires, n. 14, 13 mar. 1822. Colecciones Digitales. Biblioteca Nacional Mariano Moreno (Buenos Aires). Disponível em: https://catalogo.bn.gov.ar Acesso em: 28 ago. 2021. De forma exemplar: "La razón ha triunfado: el directorio no existe ¡No hay ya directores en América! La historia de esta magistratura, en esta parte del mundo, es la historia de la tiranía, de la corrupción, de la inmoralidad, de las depreciones, de las arbitrariedades, de los asesinatos, destierros, proscripciones, y en fin de las mayores estorsiones que se han cometido después del año 10 en las antiguas colonias españolas, es para nosotros el reinado de los Marios y Robespierres. Ella ha desaparecido ahora del todo; su nombre será tan odioso como el de los reyes á quienes pretendió suceder; y es muy notable la marcha, semejante en lo posible, que se ha seguido para su aniquilamiento, tanto en las Provincias Unidas, como en la república de Chile". El Correo de las Provincias, n. 11, 27 fev. 1822. p. 142. Disponível em: https://catalogo.bn.gov.ar Acesso em: 28 ago. 2021. Segundo informações do catálogo da Biblioteca Nacional Mariano Moreno, El Correo de las Provincias foi redigido por Fortunato Lemoyne e impresso na Imprenta Álvarez, de 19 de novembro de 1822 até 10 de abril de 1823.

${ }^{9}$ El Espiritu de Buenos Aires, n. 17, 23 mar. 1822. p. 207. Colecciones Digitales. Biblioteca Nacional Mariano Moreno (Buenos Aires). Disponível em: https://catalogo.bn.gov.ar Acesso em: 28 ago. 2021.

${ }^{10}$ El Espiritu de Buenos Aires, n. 17, 23 mar. 1822. p. 207. Colecciones Digitales. Biblioteca Nacional Mariano Moreno (Buenos Aires). Disponível em: https://catalogo.bn.gov.ar Acesso em: 28 ago. 2021.

${ }^{11}$ El Espiritu de Buenos Aires, n. 16, 20 mar. 1822. p. 189. Colecciones Digitales. Biblioteca Nacional Mariano Moreno (Buenos Aires). Disponível em: https://catalogo.bn.gov.ar Acesso em: 28 ago. 2021.
} 
Outros Tempos, vol. 19, n. 33, 2022, p. 193-229. ISSN: 1808-8031

moralidade do governo, deslocando-a da pessoa moral centrada no rei, típica da ordem de Antigo Regime, para o governo e a nação, identificada na república liberal: o "[...] gobierno es la persona moral más respetable de una nación"12. Esta perspectiva recai indiretamente sobre o rei como figura distributiva, não somente da Justiça, mas das riquezas do Estado (OLIVAL, 2001). Em um governo moral, cargos, bens e títulos era resultado do mérito e patriotismo do cidadão em relação à promoção do bem comum ou da defesa do governo e da nação. $\mathrm{O}$ rei não detinha mais o monopólio sobre a definição de critérios e a distribuição de Justiça e riquezas. Mais do que isso, o poder do rei poderia ser considerado abusivo, tal como o poder em si e seus agentes, por isso o exercício do poder deveria ser vigiado e questionado pelos cidadãos para não se tornar violento e corrupto (KOSELLECK, 1999) ${ }^{13}$.

Em uma república, a lei seria o dispositivo responsável para o controle das paixões e promoveria o exercício das virtudes e da justiça no governo, por relacionar moral, virtude, trabalho e utilidade. Em última instância, a obediência à lei pelos cidadãos de todos os escalões garantiria o gozo da liberdade, na qualidade de "[...] el primer carácter de todo gobierno republicano"14. Nesse sentido, de acordo com o redator do El Teatro de la Opinión, as "ciências morais" seriam "[...] consecuencia inmediata de las ciencias físicas, y [entrariam] en el cuadro trazado por la naturaleza" 15 para aperfeiçoamento da sociedade, "[...] mostrando al hombre los modelos que él ha de seguir, lo transportan del mundo físico al mundo moral, y seguidamente al mundo social o político [... $]^{16}$. Assim, as virtudes sociais eram definidas pela moral, dispostas para assegurar em sociedade as leis naturais e fazer prosperar o governo pelo trabalho: "En una república todos deben ser virtuosos, y la virtud consiste en el trabajo,

\footnotetext{
${ }^{12}$ El Espiritu de Buenos Aires, n. 17, 23 mar. 1822. p. 207. Colecciones Digitales. Biblioteca Nacional Mariano Moreno (Buenos Aires). Disponível em: https://catalogo.bn.gov.ar Acesso em: 28 ago. 2021.

13 Sobre o desmantelamento da noção de patrimônio real pelos liberais na monarquia espanhola, cf. CHUST, 1999. Na monarquia portuguesa cf. HESPANHA, 2004.

${ }^{14}$ El Centinela, n. 19, 1 dez. 1822. Impresso na tipografia dos Expósitos, de 28 de julho de 1822 até 7 de dezembro de 1823, totalizando 72 números, foi redigido por Florencio y Juan Cruz Varela e Don Ignacio Núñez. Tinha por epígrafe "?Quién vive? !La Patria!” (BELTRAN, 1943, p. 145-148).

${ }^{15}$ El Teatro de la Opinión, n. 4, 13 jun. 1823. p. 36-37. Colecciones Digitales. Biblioteca Nacional Mariano Moreno (Buenos Aires). Disponível em: https://catalogo.bn.gov.ar Acesso em: 28 ago. 2021. Redigido por Francisco Agustín Wright e Angel Saraiva e impresso na Imprenta de Alvarez e pela de Hallet, foi editado de 25 de maio de 1823 até 20 de agosto de 1824, totalizando 65 números (BELTRAN, 1943, p. 157-158).

${ }^{16}$ El Teatro de la Opinión, n. 4, 13 jun. 1823. p. 36-37. Colecciones Digitales. Biblioteca Nacional Mariano Moreno (Buenos Aires). Disponível em: https://catalogo.bn.gov.ar Acesso em: 28 ago. 2021.Cf. El Pacifico Oriental de Montevideo, n. 19, 26 abr. 1822. p. 161. Colecciones Digitales. Biblioteca Nacional Mariano Moreno (Buenos Aires). Disponível em: https://catalogo.bn.gov.ar Acesso em: 28 ago. 2021: "La moral es la ciencia de todos los siglos, de todas las edades y de todas las naciones, practicados sus preceptos con igual interés por todos los hombres la sociedad sería el centro de las delicias, sin ella todos son desgraciados tigres que devorando-se en el disgusto turban nuestras fruiciones más naturales al paso que sus adornos resaltan y se recomiendan en los que la poseen [...]". Redigido por Francisco de Pula Pérez, impresso na Imprenta del Comercio del Plata, circulou de 22 de dezembro de 1820 até 4 de julho de 1822, totalizando 257 edições (DEMURO, 2016, 2018, p. 143-144).
} 
Outros Tempos, vol. 19, n. 33, 2022, p. 193-229. ISSN: 1808-8031

no en un lujo inútil. Esto exige al mismo tiempo pocos gastos" ${ }^{17}$ e a dedicação total dos cidadãos à república: "Nada tiene el hombre público que no pertenezca à la república. Ella le pide cuenta hasta de las horas destinadas à su descanso [...]"18.

O desafio da constituição da república era estabelecer um conjunto de leis condizente com o "espíritu de los seres à quien se dirige"19 em termos de costumes, necessidades, paixões e ilustração, tendo em vista a "felicidad común" ou interesse público e respeitando os direitos naturais. Com essa finalidade, era necessário prescindir das paixões “[...] que producen los intereses privados, para introducir, y admitir las instituciones políticas. Es preciso calcularlo todo por el interés general” ${ }^{20}$. Em termos gerais, todo cidadão tinha o dever moral de conhecer e sustentar seus direitos, de permanecer atento ao exercício dos poderes e, por isso, era primordial que suas liberdades fossem regulamentadas de forma ampla, de modo a normatizar a participação popular durante o exercício eleitoral e no cotidiano, em todas as esferas de inserção política e de relação entre cidadãos e os poderes do governo $^{21}$. Pode-se dizer que esta seria a regulamentação dos direitos e deveres dos cidadãos em uma esfera cívica, tendo em vista uma experiência republicana (BASILE, 2004) que, em 1822 e 1823, João Soares Lisboa e outros liberais acreditavam possível dentro de uma monarquia constitucional, em semelhança ao defendido enfaticamente pelos liberais exaltados, durante o Período Regencial (MOREL, 2017, p. 249).

Essas noções reforçavam a importância do cidadão vigilante do poder, visão que levada ao limite, considerava o cidadão um agente de justiça, sustentado pela obediência à lei, ideia que ganhava mais força em um momento de formulação da Constituição ${ }^{22}$. De forma

\footnotetext{
${ }^{17}$ El Teatro de la Opinión, n. 4, 13 jun. 1823. p. 37. Colecciones Digitales. Biblioteca Nacional Mariano Moreno (Buenos Aires). Disponível em: https://catalogo.bn.gov.ar Acesso em: 28 ago. 2021.

${ }^{18}$ Revista Ligera de Buenos Aires, n. 1, 1 jan. 1822. p. 8. Colecciones Digitales. Biblioteca Nacional Mariano Moreno (Buenos Aires). Disponível em: https://catalogo.bn.gov.ar Acesso em: 28 ago. 2021.

${ }^{19}$ El Espíritu de Buenos Aires, n. 26, 13 jun. 1822. p. 309-310. Colecciones Digitales. Biblioteca Nacional Mariano Moreno (Buenos Aires). Disponível em: https://catalogo.bn.gov.ar Acesso em: 28 ago. 2021. Segundo informações do catálogo da Biblioteca Nacional Mariano Moreno, esse periódico era impresso na Imprenta Álvarez, de fevereiro de 1822 até julho de 1822, totalizando 28 edições, com a seguinte epígrafe: "El destino nos conduce a la elevación y a la prosperidad por un sistema liberal y de luces. Sigamos su influjo".

${ }^{20}$ El Espíritu de Buenos Aires, n. 26, 13 jun. 1822. p. 309-310. Colecciones Digitales. Biblioteca Nacional Mariano Moreno (Buenos Aires). Disponível em: https://catalogo.bn.gov.ar Acesso em: 28 ago. 2021.

${ }^{21}$ El Espíritu de Buenos Aires, n. 5, 9 fev. 1822. p. 47. Colecciones Digitales. Biblioteca Nacional Mariano Moreno (Buenos Aires). Disponível em: https://catalogo.bn.gov.ar Acesso em: 28 ago. 2021; El Espíritu de Buenos Aires, n. 19, 4 abr. 1822. Colecciones Digitales. Biblioteca Nacional Mariano Moreno (Buenos Aires). Disponível em: https://catalogo.bn.gov.ar Acesso em: 28 ago. 2021.

${ }^{22}$ Mônica Jacqueline Sifuentes aponta a "convivência" mesmo após a independência do ordenamento lusitano na administração da Justiça, regulada pelas Ordenações Filipinas, sendo a primeira instância formada por ouvidores gerais, corregedores, ouvidores de comarca, provedores, juízes de fora, juízes ordinários, juízes de vintena, juízes de órfãos, almotacés, alcaides e vereadores. Na segunda instância, os Tribunais de Relação do Rio de Janeiro e da Bahia e recursos admitidos no Desembargo do Paço, de Lisboa. Desde a instalação da Corte portuguesa no Rio de Janeiro, o Tribunal da Relação do Rio de Janeiro se converteu em Supremo Tribunal de Justiça,
} 
Outros Tempos, vol. 19, n. 33, 2022, p. 193-229. ISSN: 1808-8031

convergente, João Soares Lisboa mantinha a mesma proposta do seu periódico do ano anterior, assumindo que seu jornal deveria ser uma espécie de "Tribunal” de apelação pública de seus correspondentes, e reconhecendo que foi assim que ganhou importância como redator. A grande maioria das cartas publicadas, presentes de forma regular ao longo das edições do Correio do Rio de Janeiro dos meses de 1823, tratava de denúncias semelhantes às apresentadas nas edições do mesmo jornal de 1822, tais como, prisões arbitrárias, falta de transparência dos magistrados e desmandos de funcionários públicos (FERREIRA, 2017, p. 253-285). O próprio Joaquim Gonçalves Ledo, aliado e companheiro de exílio de Soares Lisboa em 1822 e, desde junho desse ano, procurador da província do Rio de Janeiro no conselho nomeado por D. Pedro, era um correspondente do jornal, tendo suas cartas publicadas sob o pseudônimo de Amante Leitor e criticando os magistrados por excederem suas atribuições (FERREIRA, 2017, p. 110-111; OLIVEIRA, 1999, p. 215-217).

Importante dizer que essa noção sobre o papel do redator e da imprensa fazia parte da caracterização do que Marco Morel (2005) chama de modernidade do espaço público. Em sua definição, o autor afirma que, a partir da segunda metade do século XVIII, especialmente, após a eclosão da Revolução Francesa, a imprensa mobilizava o fazer político em um espaço público que não era oficial ou institucionalizado e tinha ampla participação da população, movimentando um circuito de participação política dinâmico, inexistente durante o Antigo Regime (MOREL, 2005). Assim, pela imprensa, a palavra se tornava pública em um circuito de transformações políticas, econômicas e sociais que reunia senhores, escravos e homens livres. Ampliar os debates políticos dos círculos letrados para toda a população sustentava a legitimidade da opinião pública na qualidade de Rainha do Mundo, novo termômetro da política. Ao mesmo tempo, era um mecanismo pedagógico de instrução do povo sobre a opinião considerada a mais iluminada, sendo que esta não era definida necessariamente pela maioria, porém possuía um carácter mais abstrato que contava com o "[...] julgamento crítico de cada cidadão leitor" (MOREL; BARROS, 2003, p. 24-25; FERREIRA, 2011, p. 35-70). Dessa maneira, as transformações no processo de independência e construção do Estado e da nação do Brasil se relacionavam com a formação do espaço público tanto pelo que era impresso e debatido, quanto por um hibridismo de novas e tradicionais práticas culturais e

equiparado à Casa de Suplicação de Lisboa. Somente na Carta Constitucional de 1824 passou-se a utilizar o termo "Poder Judicial" (SIFUENTES, 1999, p. 326). Para a discussão do Judiciário previsto no projeto de Constituição discutido pelos deputados reunidos na Assembleia Legislativa do Brasil (1823) e do determinado na Carta (SLEMIAN, 2009, p. 125-143). Destaca-se que no projeto o Judiciário era formado por juízes e jurados, sendo os juízes de direito letrados "inamovíveis" e o "sistema de jurados" visto como direito dos cidadãos, com a participação de homens sem magistratura (SLEMIAN, 2009, p. 128). 
Outros Tempos, vol. 19, n. 33, 2022, p. 193-229. ISSN: 1808-8031

sociais (LUSTOSA, 2000; MOREL, 2005; MOREL; BARROS, 2003; NEVES, 2003; OLIVEIRA, 1999; SLEMIAN, 2006; 2009).

\section{O Correio do Rio de Janeiro em busca de justiça contra a bonifácia}

Em 1823, o Correio deixava de ser publicado na tipografia de Silva Porto, para ser impresso na de Inocêncio Francisco Torres, que convenientemente, localizava-se na Rua da Cadeia, $n^{\circ}$ 95. Apesar da falta de informações sobre essa tipografia, Soares Lisboa contava que conseguia publicar esse jornal da prisão graças à proteção e colaboração de seus amigos. Eles contribuíam com generosa e "voluntária subscrição", que garantia a sua "subsistência na prisão", e o visitavam, apesar dos riscos, para abastecê-lo de material para a sua escrita e entregar a Soares Lisboa as cartas de seus correspondentes. Por fim, recolhiam seus manuscritos para a impressão na tipografia Torres (FERREIRA, 2017, p. 254-258) ${ }^{23}$.

No número inaugural e extraordinário, vinha a público a principal estratégia de João Soares Lisboa para sua absolvição da bonifácia. Publicava uma exposição em que se defendia das acusações de "organização de um conluio republicano" e de desobedecer à ordem de exílio do Brasil e encerramento do Correio do Rio de Janeiro, com a qual admitia ter se comprometido em 1822. Prontamente, em 1823, encaminhou, junto a uma Representação aos deputados, cem exemplares dessa edição do Correio do Rio de Janeiro, sendo sua iniciativa discutida no plenário e publicada no $O E_{\text {spelho }}{ }^{24}$. Dessa maneira, João Soares Lisboa trilhava, simultaneamente, dois caminhos para sua absolvição. Em um deles apelava aos deputados para que com uma decisão do poder legislativo subordinassem a decisão ministerial, anulando as acusações. No outro recorria ao "Tribunal Público", a imprensa, atrelado à reivindicação de um júri popular. Em sua estratégia, transparecia uma visão negativa dos magistrados, desconfiando do respeito à legalidade e aos procedimentos do julgamento por essas autoridades. Também pretendia se beneficiar do júri popular que, para ele, seria convencido por suas publicações do Correio. Por fim, João Soares Lisboa dominava o vocabulário e os modos utilizados na retórica liberal para sua defesa perante a um júri, o que já mostrava nas publicações do Correio do Rio de Janeiro de 1822 quando foi inocentado no

\footnotetext{
${ }^{23}$ Correio Extraordinário do Rio de Janeiro, n. 1, 24 maio 1823. p. 7-8. Hemeroteca Digital da Biblioteca Nacional (Rio de Janeiro). Disponível em: http://bndigital.bn.gov.br/. Acesso em: 28 ago. 2021.

${ }^{24}$ O Espelho, n. 159, 27 maio 1823. Hemeroteca Digital da Biblioteca Nacional (Rio de Janeiro). Disponível em: http://bndigital.bn.gov.br/. Acesso em: 28 ago. 2021; O Espelho, n. 160, 30 maio 1823. Hemeroteca Digital da Biblioteca Nacional (Rio de Janeiro). Disponível em: http://bndigital.bn.gov.br Acesso em: 28 ago. 2021. e nas sessões de 26 e 28/8 de maio de 1823 e 2 de junho de 1823 (DIÁRIO da Assembleia Geral Constituinte e Legislativa do Império do Brasil, 1823. Brasília, DF: Senado Federal, 2003. p. 121-122, 146, 162).
} 
Outros Tempos, vol. 19, n. 33, 2022, p. 193-229. ISSN: 1808-8031

processo por “[...] abuso da liberdade de imprensa" (FERREIRA, 2017, p. 94-124; LUSTOSA, 2000, p. 174-181; NEVES, 2003, p. 344-354).

O texto do Correio Extraordinário do Rio de Janeiro era de uma carta dirigida aos deputados, iniciada com a dramaticidade nas descrições sobre as condições da cadeia que marcaram as publicações do Correio do Rio de Janeiro no ano de 1823: “Quem está em cárcere não vive, vegeta" ${ }^{25}$. Continuava sua carta dizendo que era unanimidade entre os seus "Concidadãos, amigos, e inimigos" que o motivo que o levou a "arrastar grilhões" foi o de ter escrito, "na primeira parte" do Correio do Rio de Janeiro, "[...] talvez demasiado, amor da bem entendida Liberdade" ${ }^{26}$. Entretanto, justificava-se que "[...] se é que no desejo deste precioso tesouro, pode chamar-se excesso ao que escrevemos" ${ }^{27}$. Finalizava com o pedido aos deputados que lhe restituíssem a "[...] própria liberdade para gozar da vida, pois que esta sem aquela é um fardo insuportável"28.

O redator retomava a utilidade pública do Correio do Rio de Janeiro, argumentando que pelo debate publicado em seu jornal fomentava o consenso entre os cidadãos de todas as "hierarquias" e "estados", eximindo-se como redator de "ilustrar e dirigir" o público e a opinião pública porque isso se realizaria pelo debate publicado na sessão correspondência do Correio. Explicava que, com os "olhos na lei, respeitando o sistema adotado pela Nação", consultava sua "consciência" e guiado pela "convicção" de sua alma, escrevia "sem rebuço", fazendo da imprensa o "[...] supremo Tribunal da opinião pública"29. Isto é, a redação do periódico dependia mais da adesão aos princípios constitucionais da nação do que da sua ilustração, sinalizando para uma ampliação da participação na política dos cidadãos letrados sem formação em instituições formais de educação, mediados pela imprensa. Esse esclarecimento também era uma forma de recuperar a sua trajetória como protagonista na convocação das Cortes do Brasil, em defesa da monarquia constitucional, rebatendo a indicação das publicações do Correio do Rio de Janeiro de 1822 arroladas nessa devassa como provas que o incriminavam de "conluio republicano".

\footnotetext{
25 Correio Extraordinário do Rio de Janeiro, n. 1, 24 maio 1823. p. 1. Hemeroteca Digital da Biblioteca Nacional (Rio de Janeiro). Disponível em: http://bndigital.bn.gov.br Acesso em: 28 ago. 2021.

${ }^{26}$ Correio Extraordinário do Rio de Janeiro, n. 1, 24 maio 1823. p. 1. Hemeroteca Digital da Biblioteca Nacional (Rio de Janeiro). Disponível em: http://bndigital.bn.gov.br/ Acesso em: 28 ago. 2021.

27 Correio Extraordinário do Rio de Janeiro, n. 1, 24 maio 1823. p. 1. Hemeroteca Digital da Biblioteca Nacional (Rio de Janeiro). Disponível em: http://bndigital.bn.gov.br Acesso em: 28 ago. 2021.

28 Correio Extraordinário do Rio de Janeiro, n. 1, 24 maio 1823. p. 1. Hemeroteca Digital da Biblioteca Nacional (Rio de Janeiro). Disponível em: http://bndigital.bn.gov.br Acesso em: 28 ago. 2021.

${ }^{29}$ Correio Extraordinário do Rio de Janeiro, n. 1, 24 maio 1823. p. 2. Hemeroteca Digital da Biblioteca Nacional (Rio de Janeiro). Disponível em: http://bndigital.bn.gov.br Acesso em: 28 ago. 2021.
} 
Outros Tempos, vol. 19, n. 33, 2022, p. 193-229. ISSN: 1808-8031

$\mathrm{Na}$ carta aos deputados, apresentava a mesma postura que no seu testemunho na devassa. Reafirmava sua "conduta", "familiarizado com os trabalhos" que envolviam o "amor da bem entendida Liberdade" e declarava que "jamais" deixaria de "[...] sustentar o mesmo caráter, e pugnar pelos sagrados direitos do homem" ${ }^{30}$. Como não via crime em sua atuação, Soares Lisboa não negava que "tinha relações em Buenos Aires com alguns desses espanhóis" que a testemunha, o cônsul do Brasil em Buenos Aires, Antônio Correia da Câmara, nomeava de "inimigos do Brasil"; também confessava a sua comunicação com Joaquim Rodrigues da Costa Simões, alferes do Batalhão de Caçadores (SCHIAVINATTO; FERREIRA, 2014b, p. 287-348, 343-344). Soares Lisboa apostava na imprensa como o lugar privilegiado para esclarecer a constitucionalidade de seus atos, não admitindo fazê-lo perante a magistratura. Para não "agravar" "uma ferida que ainda tem remédio", preferia silenciar sobre a "causa" de sua "deportação" para Buenos Aires, mas insinuava ser motivada por "vinganças particulares". Não mencionava o cônsul Câmara, contudo colocava seu testemunho em dúvida, descrevendo que ele, "fingido zelo", o acusou para se promover por vingança, "[...] fanha, e raiva muitas vezes motivada por baixa emulação" ${ }^{\prime 3}$.

A próxima providência de João Soares Lisboa em sua carta era explicitar o conteúdo e os significados que alguns termos políticos tinham para ele. Focava justamente nos que mais controvérsias produziam na imprensa e que até então era, na maioria das vezes, publicado no Correio do Rio de Janeiro nas entrelinhas de seus comentários, no combate de outros redatores ou valendo-se das ideias de seus correspondentes. Nesse sentido, a carta enviada aos deputados e sua publicação marcou o momento em que Soares Lisboa assumia publicamente sua radicalidade, o que, para ele, confirmava sua constitucionalidade, justificava suas ações, absolveria sua reputação e o livraria da prisão e da devassa.

No Correio do Rio de Janeiro, João Soares Lisboa desenvolvia o princípio que “Todos os homens nascem iguais", com "direitos imperceptíveis e inalienáveis" à vida, liberdade e promoção de "sua felicidade", sendo os governantes exclusivamente responsáveis por garantir esses direitos ${ }^{32}$. Por essa razão, o "[...] não [tinham] por si nenhum poder, nem gozão de mais autoridade do que daquela que de boamente lhes querem conceder os

\footnotetext{
30 Correio Extraordinário do Rio de Janeiro, n. 1, 24 maio 1823. p. 2. Hemeroteca Digital da Biblioteca Nacional (Rio de Janeiro). Disponível em: http://bndigital.bn.gov.br/ Acesso em: 28 ago. 2021.

31 Correio Extraordinário do Rio de Janeiro, n. 1, 24 maio 1823. p. 2. Hemeroteca Digital da Biblioteca Nacional (Rio de Janeiro). Disponível em: http://bndigital.bn.gov.br Acesso em: 28 ago. 2021.

${ }^{32}$ Correio Extraordinário do Rio de Janeiro, n. 1, 24 maio 1823. p. 2-4. Hemeroteca Digital da Biblioteca Nacional (Rio de Janeiro). Disponível em: http://bndigital.bn.gov.br Acesso em: 28 ago. 2021.
} 
Outros Tempos, vol. 19, n. 33, 2022, p. 193-229. ISSN: 1808-8031

governados" 33 . Explicava que, na impossibilidade da nação exercer "[...] simultaneamente e promiscuamente a Soberania"34, era necessário separar o Poder Soberano do seu exercício, sendo delegado aos representantes que o exerciam tão somente quando reunidos na Assembleia Constituinte. De toda forma, para ele, a "origem de todos os Poderes" era os "[...] direitos naturais do homem"35.

Assim, como uma "verdade matemática em política", o "sistema Representativo" de nenhum modo "admite pluralidade de soberanias". Afirmava o "axioma político" que a soberania era "indivisível e inalienável”. Sem mencionar, o redator retomava as ideias de Civique de Gastine, traduzidas e publicadas no Correio do Rio de Janeiro em 1822 (FERREIRA, 2020a), para defender que o cidadão delegava o "[...] exercício do Poder Soberano, e não a mesma Soberania, porque esta lhe é inerente e ligada a sua existência como homem livre; o contrário lhe tornaria escravo, e não pode supor-se tal absurdo em nenhum ente racional" 36 . Desse modo, Soares Lisboa destacava que o "povo" não abria mão em nenhum momento da "Soberania", representado politicamente pela "Nação". Nesta residia “essencialmente” a Soberania e lhe competia elaborar a sua Constituição ${ }^{37}$.

Outro "axioma político" definido por João Soares Lisboa era que a nação era livre e independente, não sendo "[...] patrimônio de nenhuma pessoa ou família" ${ }^{38}$, contestando o direito real à nação. Apesar de considerar ser mais "prudente" evitar ao máximo o rompimento, isso justificava o "justo direito" do "povo" de "insurreição" no caso de uma "forma de governo destruidora" que o "escravizasse" e sujeitasse "ao despotismo absoluto" 39 . Nesse caso, o "Povo" estava autorizado a "alterar", "mudar", "abolir" o governo e "organizar seus poderes políticos do modo" que considerava "[...] mais conveniente, para afiançar sua segurança e conseguir sua prosperidade" 40 . Com esses dois axiomas, de forma a dar protagonismo a "Soberania do Povo", Soares Lisboa condicionava a autoridade e a

\footnotetext{
${ }_{33}$ Correio Extraordinário do Rio de Janeiro, n. 1, 24 maio 1823. p. 2-4. Hemeroteca Digital da Biblioteca Nacional (Rio de Janeiro). Disponível em: http://bndigital.bn.gov.br Acesso em: 28 ago. 2021.

${ }^{34}$ Correio Extraordinário do Rio de Janeiro, n. 1, 24 maio 1823. p. 2-4. Hemeroteca Digital da Biblioteca Nacional (Rio de Janeiro). Disponível em: http://bndigital.bn.gov.br Acesso em: 28 ago. 2021.

35 Correio Extraordinário do Rio de Janeiro, n. 1, 24 maio 1823. p. 2-4. Hemeroteca Digital da Biblioteca Nacional (Rio de Janeiro). Disponível em: http://bndigital.bn.gov.br Acesso em: 28 ago. 2021.

${ }^{36}$ Correio Extraordinário do Rio de Janeiro, n. 1, 24 maio 1823. p. 2-4. Hemeroteca Digital da Biblioteca Nacional (Rio de Janeiro). Disponível em: http://bndigital.bn.gov.br Acesso em: 28 ago. 2021.

37 Correio Extraordinário do Rio de Janeiro, n. 1, 24 maio 1823. p. 2-4.Hemeroteca Digital da Biblioteca Nacional (Rio de Janeiro). Disponível em: http://bndigital.bn.gov.br Acesso em: 28 ago. 2021.

38 Correio Extraordinário do Rio de Janeiro, n. 1, 24 maio 1823. p. 3-4. Hemeroteca Digital da Biblioteca Nacional (Rio de Janeiro). Disponível em: http://bndigital.bn.gov.br Acesso em: 28 ago. 2021.

39 Correio Extraordinário do Rio de Janeiro, n. 1, 24 maio 1823. p. 3-4. Hemeroteca Digital da Biblioteca Nacional (Rio de Janeiro). Disponível em: http://bndigital.bn.gov.br Acesso em: 28 ago. 2021.

${ }^{40}$ Correio Extraordinário do Rio de Janeiro, n. 1, 24 maio 1823. p. 3-4. Hemeroteca Digital da Biblioteca Nacional (Rio de Janeiro). Disponível em: http://bndigital.bn.gov.br Acesso em: 28 ago. 2021.
} 
Outros Tempos, vol. 19, n. 33, 2022, p. 193-229. ISSN: 1808-8031

estabilidade do poder da Assembleia Legislativa à "vontade do Povo" e ao seu direito de insurreição, subordinava o rei como "Súdito da Nação" e despossuía a dinastia de Bragança da posse do Brasil ${ }^{41}$.

João Soares Lisboa entendia que era obrigação dos deputados reunidos na Assembleia Legislativa o exercício de seus "Poderes Soberanos”, “[...] segundo os princípios imutáveis da natureza" ${ }^{42}$, para constituírem um governo que "[...] afiance o maior grau de felicidade comum, com o menor gravame possível, debaixo do Sistema Representativo"43. Para ele, as decisões tomadas pela Assembleia eram revestidas da "autoridade" da "Lei suprema", subordinando qualquer medida decidida nas Câmaras que "não representam o povo, mas sim representam pelo povo"44. Além disso, não deviam temer nem a reação de D. Pedro I, que deveria ser respeitado como "Primeiro Magistrado da Nação", tampouco dos militares, vistos como cidadãos armados e, por isso, confiáveis: “A espada do aventureiro Militar assalariado e embrutecido, entroniza o despotismo, mas a espada do Cidadão Militar amante da sua pátria aniquila o despotismo"45. Por fim, era imprescindível a prevalência do poder legislativo sobre o exercício da Justiça, os deputados deveriam “[...] reformar abusos inveterados, principalmente na repartição judiciária! O poderio da gente Togada é colossal; seu despotismo e arbitrariedade é transcendente e prejudicial a toda a classe de Cidadãos"46.

A partir disso, João Soares Lisboa apresentava dispositivos de controle dos agentes do judiciário, sobretudo, pelo legislativo, mas também pelo executivo. Essa descrição também justificava o requerimento de revisão do seu processo, anexado à carta dirigida aos deputados. Defendia o direito de petição do réu primeiro ao executivo e depois ao legislativo e o de "vistoria" do processo pelo último órgão, com a finalidade de verificar se "[...] existe infração da Lei para ordenar o castigo aos infratores" ${ }^{47}$. Esse procedimento garantiria a efetividade da lei, pois “[...] não basta fazerem-se boas Leis”, era “[...] necessário fazer efetiva

\footnotetext{
${ }^{41}$ Correio Extraordinário do Rio de Janeiro, n. 1, 24 maio 1823. p. 3-4. Hemeroteca Digital da Biblioteca Nacional (Rio de Janeiro). Disponível em: http://bndigital.bn.gov.br Acesso em: 28 ago. 2021.

${ }^{42}$ Correio Extraordinário do Rio de Janeiro, n. 1, 24 maio 1823. p. 4-6. Hemeroteca Digital da Biblioteca Nacional (Rio de Janeiro). Disponível em: http://bndigital.bn.gov.br Acesso em: 28 ago. 2021.

${ }^{43}$ Correio Extraordinário do Rio de Janeiro, n. 1, 24 maio 1823. p. 4-6. Hemeroteca Digital da Biblioteca Nacional (Rio de Janeiro). Disponível em: http://bndigital.bn.gov.br Acesso em: 28 ago. 2021.

${ }^{44}$ Correio Extraordinário do Rio de Janeiro, n. 1, 24 maio 1823. p. 4-6. Hemeroteca Digital da Biblioteca Nacional (Rio de Janeiro). Disponível em: http://bndigital.bn.gov.br Acesso em: 28 ago. 2021.

45 Correio Extraordinário do Rio de Janeiro, n. 1, 24 maio 1823. p. 4-6. Hemeroteca Digital da Biblioteca Nacional (Rio de Janeiro). Disponível em: http://bndigital.bn.gov.br Acesso em: 28 ago. 2021.

${ }^{46}$ Correio Extraordinário do Rio de Janeiro, n. 1, 24 maio 1823. p. 4-6. Hemeroteca Digital da Biblioteca Nacional (Rio de Janeiro). Disponível em: http://bndigital.bn.gov.br Acesso em: 28 ago. 2021.

47 Correio Extraordinário do Rio de Janeiro, n. 1, 24 maio 1823. p. 7. Hemeroteca Digital da Biblioteca Nacional (Rio de Janeiro). Disponível em: http://bndigital.bn.gov.br Acesso em: 28 ago. 2021.
} 
Outros Tempos, vol. 19, n. 33, 2022, p. 193-229. ISSN: 1808-8031

sua pontual e literal execução"48. No caso de provada a ingerência dos magistrados, Soares Lisboa defendia a indenização ao "injustiçado"49.

João Soares Lisboa finalizava sua carta aos deputados justificando que retornou prematuramente de Buenos Aires para continuar a redação do Correio do Rio de Janeiro porque estava convicto de um novo "tempo" em que a Assembleia Legislativa era superior ao Ministério. Relatava que confiava em sua inocência e no respeito à determinação da lei de que o "abuso" nas publicações de um jornal deveria ser julgado por um júri. Ele já havia sido absolvido das acusações de "abuso da liberdade de imprensa" em 1822, julgado conforme o decreto que regulava a liberdade de imprensa, de 18 de junho do mesmo ano. Nesse, os autores eram responsabilizados por abusos contra a moral, a religião e o governo e incluía, conforme a lei portuguesa de 14 de julho de 1821, a criação de um júri popular para o julgamento desses casos (FERREIRA, 2011, p. 35-70; NEVES, 2003, p. 351). Para os trâmites do julgamento, a lei determinava que se reunissem "[...] vinte e quatro cidadãos escolhidos dentre os homens bons, honrados, inteligentes e patriotas, os quais serão Juízes de Fato, para conhecerem da criminalidade dos Escritos abusivos" ${ }^{\circ 0}$. Dentre esses homens, os réus poderiam recusar dezesseis, mantendo o corpo final com oito membros, e era permitida a apresentação de uma defesa. No caso de culpa, a pena deveria ser estabelecida pelo juiz que agiria conforme a lei definida nas Cortes de Lisboa, e a apelação era reservada ao rei que poderia ou não conceder "clemência" ${ }^{51}$. Assim, apesar da participação do juiz, os julgamentos dos casos relativos à imprensa eram protagonizados por cidadãos que, para Soares Lisboa, eram agentes mais confiáveis do que os "togados" 52 .

Sobre a acusação de descumprimento do termo assinado por João Soares Lisboa em 1822, que determinava seu exílio e o encerramento do Correio do Rio de Janeiro, ele argumentava que era uma "ordem" ministerial inferior em "respeito" à lei sobre o "abuso da liberdade de imprensa". Concluía pedindo a "indulgência" dos deputados, imperador e cidadãos $^{53}$. Por fim, na sessão do dia 26 de maio de 1823, cem exemplares dessa edição do

\footnotetext{
48 Correio Extraordinário do Rio de Janeiro, n. 1, 24 maio 1823. p. 7. Hemeroteca Digital da Biblioteca Nacional (Rio de Janeiro). Disponível em: http://bndigital.bn.gov.br Acesso em: 28 ago. 2021.

49 Correio Extraordinário do Rio de Janeiro, n. 1, 24 maio 1823. p. 7. Hemeroteca Digital da Biblioteca Nacional (Rio de Janeiro). Disponível em: http://bndigital.bn.gov.br Acesso em: 28 ago. 2021.

${ }^{50}$ Correio do Rio de Janeiro, n. 59, 22 jun. 1822. p. 241-242. Hemeroteca Digital da Biblioteca Nacional (Rio de Janeiro). Disponível em: http://bndigital.bn.gov.br Acesso em: 28 ago. 2021.

${ }^{51}$ Correio do Rio de Janeiro, n. 59, 22 jun. 1822. p. 241-242. Hemeroteca Digital da Biblioteca Nacional (Rio de Janeiro). Disponível em: http://bndigital.bn.gov.br Acesso em: 28 ago. 2021.

${ }^{52}$ Sobre os debates entre deputados e redatores sobre a liberdade de imprensa desde as Cortes de Lisboa até 1840 no Império do Brasil. Cf. FERREIRA, 2011, p. 35-69; NUNES, 2010.

${ }^{53}$ Correio Extraordinário do Rio de Janeiro, n. 1, 24 maio 1823. p. 7-8. Hemeroteca Digital da Biblioteca Nacional (Rio de Janeiro). Disponível em: http://bndigital.bn.gov.br Acesso em: 28 ago. 2021.
} 
Outros Tempos, vol. 19, n. 33, 2022, p. 193-229. ISSN: 1808-8031

Correio do Rio de Janeiro foram recebidos pelos deputados, junto a uma Representação de sua autoria que foi publicada na íntegra no Diário da Assembleia Legislativa do Brasil ${ }^{54}$.

\section{A condenação e a defesa pública contra a bonifácia}

No dia 5 de julho de 1823, João Soares Lisboa foi o único condenado na devassa que processava um "conluio republicano", apresentando os primeiros sinais de rompimento com homens que, junto a ele, eram réus no mesmo processo. A condenação produziu dois movimentos nas publicações posteriores do Correio do Rio de Janeiro. Um deles foi a divulgação de sua defesa pública, discutindo a legitimidade da acusação e, outro, a objeção aos procedimentos que envolveram a devassa e a absolvição dos outros réus, discutindo o exercício da justiça no Império do Brasil (OLIVEIRA, 1999, p. 296-297). De toda forma, a condenação marcou a sua memória com a pecha de republicano, registrada nos testemunhos contra ele arrolados no inquérito da devassa, sendo Soares Lisboa colocado à sombra de Joaquim Gonçalves Ledo, ou como radical e republicano. Essa versão ganhou repercussão na literatura histórica, tornando-se uma questão historiográfica nas obras de autores como Mello Moraes e Varnhagen, publicadas no século XIX, e em obras de Otávio Tarquínio de Souza, Oliveira Lima, Caio Prado Junior, Emília Viotti e Nelson Werneck Sodré, produzidas no século $\mathrm{XX}^{55}$. Para isso foi decisiva a publicação do Processo dos Cidadãos, em 1824, e igualmente, o esquecimento ${ }^{56}$ da defesa pública de Soares Lisboa, disseminada no Correio do Rio de Janeiro (FERREIRA, 2014; 2017, p. 335-344; SCHIAVINATTO; FERREIRA, 2014a).

Em um movimento de criação e divulgação de "reputações públicas", de memórias e depois na institucionalização da História, a contestação e defesa de João Soares Lisboa contra a bonifácia publicada no Correio do Rio de Janeiro e apresentada aos deputados brasileiros foram relegadas na literatura histórica por esses autores que escreveram

\footnotetext{
${ }^{54}$ Sobre a discussão na Assembleia Legislativa da Representação e dos exemplares do Correio do Rio de Janeiro enviados por Soares Lisboa aos deputados, bem como a repercussão disso no O Espelho, Cf. FERREIRA, 2017 , p. 262-267.

${ }^{55}$ A fortuna crítica da trajetória de João Soares Lisboa foi analisada nas obras de Mello Moraes, Brasil Histórico (1866) e A Independência e o Império do Brasil (1877), e em História da Independência do Brasil (1875) de Varnhagen (FERREIRA, 2014; 2017, p. 14-29; OLIVEIRA, 1999, p. 296-297; SCHIAVINATTO; FERREIRA, 2014a). De Tarquínio, se refere às obras José Bonifácio (1945) e A vida de D. Pedro I (1952). Jorge Vinícius Monteiro Vianna analisa a questão nas obras dos outros mencionados autores produzidas no século XX (VIANNA, 2011, p. 9-16).

56 Esquecimento relacionado a uma memória da disciplina no sentido proposto por Manoel Luiz Salgado Guimarães: "[...] Memória [da disciplina] que, como todo exercício de lembrança, procede a escolhas a partir de um jogo complexo em que o lembrar supõe necessariamente o esquecer. O esquecer entendido não como o ato de 'falta de lembrança' mas como procedimento social que se inscreve em toda cultura histórica." (GUIMARÃES, 2002, p. 13-48; GUIMARÃES, 2003, p. 10).
} 
Outros Tempos, vol. 19, n. 33, 2022, p. 193-229. ISSN: 1808-8031

a História do Brasil. Isso porque, sobretudo, sua versão desestabilizava a imagem que se criava dos outros réus nessas obras. Igualmente, no Processo dos Cidadãos (1824), ela foi obliterada ou marginalizada, já que sua publicação foi motivada pela apresentação pública das absolvições dos outros réus, que se tornaram figuras proeminentes no Império depois da dissolução da Assembleia Legislativa em novembro de 1823 e a outorga da Carta Constitucional (FERREIRA, 2014; 2017, p. 1-29).

\section{O Correio do Rio de Janeiro analisando a devassa}

No dia 12 de julho de 1823, João Soares Lisboa publicava a sua pena de condenação a dez anos de prisão, cem mil réis e as "custas" dos processos de todos os outros réus absolvidos por falta de provas. Soares Lisboa se dirigia aos "senhores Togados" para lembrá-los que a "[...] vontade [do Togado] não é Lei" ${ }^{57}$ e que recorreria a D. Pedro I para argumentar que a sentença era "injusta" (porque não cometeu crime) e "arbitrária”, pois "a proferiram sobre a doutrina de um Periódico, que a Lei manda julgar por um Júri” ${ }^{\circ 8}$. No Correio do Rio de Janeiro, seu redator propunha a discussão de sua pena de maneira didática, elencando cada uma das acusações arroladas pelos magistrados sem "fastidiosa e inútil" "narração de termos forenses"59.

O primeiro ponto era a acusação de sua "Associação" aos "conspiradores contra o Governo e Ministério" ${ }^{60}$. No Correio do Rio de Janeiro, Soares Lisboa explicava e contestava a sua condenação, inclusive, em relação à absolvição dos outros réus, rompendo definitivamente com seus antigos aliados e contribuindo para que sua trajetória pública fosse postergada pelas Histórias do Brasil da segunda metade do século XIX e do século XX, como já mencionado. Tal como publicado no Processo dos Cidadãos (1824), João Soares Lisboa caracterizava a demissão de José Bonifácio de Andrada do ministério, em 30 de outubro de 1822, como uma "vergonhosa farsa"61 para eliminar toda e qualquer oposição às suas medidas. Depois de sua restituição ao ministério, José Bonifácio de Andrada “inventou” a

\footnotetext{
${ }^{57}$ Correio Extraordinário do Rio de Janeiro, n. 3, 12 jul. 1823. p. 13. Hemeroteca Digital da Biblioteca Nacional (Rio de Janeiro). Disponível em: http://bndigital.bn.gov.br Acesso em: 28 ago. 2021.

${ }^{58}$ Correio Extraordinário do Rio de Janeiro, n. 3, 12 jul. 1823. p. 13. Hemeroteca Digital da Biblioteca Nacional (Rio de Janeiro). Disponível em: http://bndigital.bn.gov.br Acesso em: 28 ago. 2021.

${ }^{59}$ Correio Extraordinário do Rio de Janeiro, n. 3, 12 jul. 1823. p. 13. Hemeroteca Digital da Biblioteca Nacional (Rio de Janeiro). Disponível em: http://bndigital.bn.gov.br/ Acesso em: 28 ago. 2021.

${ }^{60}$ Correio Extraordinário do Rio de Janeiro, n. 7, 23 jul. 1823. p. 31. Hemeroteca Digital da Biblioteca Nacional (Rio de Janeiro). Disponível em: http://bndigital.bn.gov.br Acesso em: 28 ago. 2021.

${ }^{61}$ Correio Extraordinário do Rio de Janeiro, n. 5, 19 jul. 1823. p. 25. Hemeroteca Digital da Biblioteca Nacional (Rio de Janeiro). Disponível em: http://bndigital.bn.gov.br/ Acesso em: 28 ago. 2021.
} 
Outros Tempos, vol. 19, n. 33, 2022, p. 193-229. ISSN: 1808-8031

"existência" de uma "[...] sociedade de conspiradores contra o Governo, ou Ministério!!!" com o fim de "[...] desviar a atenção pública, do conhecimento daquela farsa" ${ }^{63}$ e iniciarem um governo de "despotismo" 64 .

De acordo com a versão de Soares Lisboa, esse quadro se perpetuou graças ao “[...] insolente orgulho, baixas vinganças, sórdidas intrigas, e grosseiros erros políticos com que tais Andradas levaram o império às bordas do sepulcro" ${ }^{65}$. Isso só foi percebido por D. Pedro I em 1823, quando "o terrorismo (sistema favorito dos déspotas) com que eles puseram em comoção as Províncias", estava "prestes (se o dedo da Providência não obstar) a sofrer o mais terrível dos flagelos - a anarquia - da qual resultará a extinção do nome 'Império!'”. Esses "males", "quase irremediáveis", “tocaram o coração de S. M. I.”, que prontamente demitiu os Andradas, o que para Soares Lisboa deveria "eternizar Seu Nome como Herói” no "Templo da Memória"66.

Ainda de acordo com Soares Lisboa, o plano de José Bonifácio de Andrada foi articulado desde sua nomeação ao ministério em janeiro de 1822, quando ele propôs a D. Pedro que "só aceitaria o Emprego" se D. Pedro lhe comunicasse "todos os Seus segredos" e só agiria conforme o “consentimento e aprovação do Ministro!!!". Para Soares Lisboa, o então príncipe regente, por sua "candura" e sem prever as consequências disso, acreditou na boa vontade de José Bonifácio de Andrada e aceitou a sua proposta. Nessa versão, o ministro José Bonifácio de Andrada era "desleixado", "desmedido", tinha um "orgulho intolerável, e fanatismo de suas opiniões", uma "hidrófila sede" de "mandar", e os Andradas governavam conforme seus interesses particulares. Caso fossem contrariados ou refutados, os Andradas chamavam e processavam seus opositores como "Demagogos", "Republicanos" e "Anarquistas"67. Destaca-se a preocupação de Soares Lisboa em responsabilizar o “despotismo ministerial" e retirar qualquer culpa de D. Pedro I a respeito dessas medidas, mecanismo que foi também essencial na narrativa da história desse período publicada no

\footnotetext{
${ }^{62}$ Correio Extraordinário do Rio de Janeiro, n. 7, 23 jul. 1823. p. 33. Hemeroteca Digital da Biblioteca Nacional (Rio de Janeiro). Disponível em: http://bndigital.bn.gov.br/ Acesso em: 28 ago. 2021.

${ }^{63}$ Correio Extraordinário do Rio de Janeiro, n. 7, 23 jul. 1823. p. 33. Hemeroteca Digital da Biblioteca Nacional (Rio de Janeiro). Disponível em: http://bndigital.bn.gov.br/ Acesso em: 28 ago. 2021.

${ }^{64}$ Correio Extraordinário do Rio de Janeiro, n. 7, 23 jul. 1823. p. 33. Hemeroteca Digital da Biblioteca Nacional (Rio de Janeiro). Disponível em: http://bndigital.bn.gov.br/ Acesso em: 28 ago. 2021.

${ }^{65}$ Correio Extraordinário do Rio de Janeiro, n. 5, 19 jul. 1823. p. 25. Hemeroteca Digital da Biblioteca Nacional (Rio de Janeiro). Disponível em: http://bndigital.bn.gov.br/ Acesso em: 28 ago. 2021.

${ }^{66}$ Correio Extraordinário do Rio de Janeiro, n. 5, 19 jul. 1823. p. 25. Hemeroteca Digital da Biblioteca Nacional (Rio de Janeiro). Disponível em: http://bndigital.bn.gov.br/ Acesso em: 28 ago. 2021.

${ }^{67}$ Correio Extraordinário do Rio de Janeiro, n. 7, 23 jul. 1823. p. 33. Hemeroteca Digital da Biblioteca Nacional (Rio de Janeiro). Disponível em: http://bndigital.bn.gov.br Acesso em: 28 ago. 2021; Correio do Rio de Janeiro, n. 92, 19 nov. 1823. p. 365-366. Hemeroteca Digital da Biblioteca Nacional (Rio de Janeiro). Disponível em: http://bndigital.bn.gov.br Acesso em: 28 ago. 2021.
} 
Outros Tempos, vol. 19, n. 33, 2022, p. 193-229. ISSN: 1808-8031

Processo dos Cidadãos (1824). Desse modo, o Correio do Rio de Janeiro e o Processo dos Cidadãos apresentavam uma narrativa da história da independência que resguardava o protagonismo e alçava D. Pedro e a dinastia de Bragança a heróis do Brasil, o que era fundamental para recolocar os antigos réus da bonifácia em lugares de prestígio ao lado do imperador, inclusive, depois da dissolução da Assembleia Legislativa e da outorga da Constituição de 1824. Ademais, pode-se dizer, essa versão se perpetuou na História do Brasil em autores como Mello Morais e Varnhagen (FERREIRA, 2017, p. 1-29).

\section{A segunda "base" analisada por João Soares Lisboa no Correio do Rio de Janeiro} foi o "suposto abuso de liberdade de imprensa". Nesse ponto, retomava sua argumentação sobre a ingerência do julgamento da produção de um jornal que supostamente continha “doutrinas criminosas", em um processo crime comum e não perante a um júri, convocado conforme a lei que regulava a liberdade de imprensa ${ }^{68}$. Além disso, discordava dos procedimentos e formas pelas quais os testemunhos contra ele foram recolhidos. Esses dois pontos foram registrados no Processo dos Cidadãos e serviram na defesa apresentada pelo advogado dos réus e nos comentários à devassa ${ }^{69}$. Apesar disso, ao analisar os testemunhos contra João Soares Lisboa arrolados nessa devassa e publicados no Processo dos Cidadãos, é possível relacioná-los à simplificação da trajetória de Soares Lisboa contida na pecha de republicano que seus opositores registravam nos testemunhos, em suas denúncias e avaliações sobre suas publicações do Correio do Rio de Janeiro (FERREIRA, 2017, p. 273-274).

No Correio do Rio de Janeiro, João Soares Lisboa desacreditava os testemunhos contra ele, afirmando serem repletos de "[...] contradições, estultas sandices, e invectivas!"70, fundados no que "[...] ouviram dizer, não sabem onde, e menos quem!!!"71. Esses mesmos argumentos eram repetidos inúmeras vezes nos comentários das testemunhas, registrados no Processo dos Cidadãos, em 1824 (SCHIAVINATTO; FERREIRA, 2014a). Soares Lisboa

\footnotetext{
${ }^{68}$ Correio Extraordinário do Rio de Janeiro, n. 8, 24 jul. 1823. p. 35-36. Hemeroteca Digital da Biblioteca Nacional (Rio de Janeiro). Disponível em: http://bndigital.bn.gov.br Acesso em: 28 ago. 2021. As publicações do Correio do Rio de Janeiro arroladas foram as n. 156 e 157, de 18 e 19 de out. de 1822 (SCHIAVINATTO; FERREIRA, 2014b, p. 287-348, 316).

${ }^{69}$ Por exemplo, no Processo dos Cidadãos, na nota ao testemunho de José Joaquim da Rocha: "Nota 26: Não compete a esta nota defender as doutrinas que a testemunha acusa, mas se eram más, responda o Procurador do Império, e Soberania Nacional porque não chamou o seu autor ao Tribunal dos Jurados" (SCHIAVINATTO; FERREIRA, 2014b, p. 260). Na defesa apresentada pelo advogado: "Mas sem entrar no merecimento das doutrinas do sobredito Jornal, digo que delas se não tira prova, nem ainda mesmo indício, de que aqueles que as escreveram fossem conspiradores contra o Governo Constitucional estabelecido, e quando envolvam algumas ideias desorganizadoras e subversivas, era no Tribunal competente dos Jurados, criado por decreto de 18 de junho de 1822 que seus autores deviam ser julgados [...]" (SCHIAVINATTO; FERREIRA, 2014c, p. 304).

${ }^{70}$ Correio Extraordinário do Rio de Janeiro, n. 9, 26 jul. 1823. p. 41. Hemeroteca Digital da Biblioteca Nacional (Rio de Janeiro). Disponível em: http://bndigital.bn.gov.br Acesso em: 28 ago. 2021.

${ }^{71}$ Correio Extraordinário do Rio de Janeiro, n. 9, 26 jul. 1823. p. 41. Hemeroteca Digital da Biblioteca Nacional (Rio de Janeiro). Disponível em: http://bndigital.bn.gov.br Acesso em: 28 ago. 2021.
} 
Outros Tempos, vol. 19, n. 33, 2022, p. 193-229. ISSN: 1808-8031

também denunciava que sua "deportação" foi feita de "plano combinado" para em sua ausência produzirem provas que o condenassem ${ }^{72}$.

Sobre seu interrogatório que durou cinco horas, João Soares Lisboa denunciava o juiz que tinha a intenção de incriminá-lo e, para isso, usava de "subterfúgios" nas suas "interrogações" que não apuravam os acontecimentos, mas tinham o objetivo de envolvê-lo “em questões de opinião sobre matérias políticas". Por fim, destacava a desproporcionalidade da situação, sentindo-se acuado e assediado pela autoridade "magistral" do juiz e pela falta de público. Sua insistência para o julgamento perante o júri popular, ou na sua defesa pública no Correio do Rio de Janeiro, indica que eram as únicas maneiras, dinâmicas e locais de onde se sentia habilitado para argumentar contra a autoridade do magistrado. Isso porque perante o júri popular e pela imprensa, Soares Lisboa contava com o seu prestígio público e com a vigilância do júri sobre os procedimentos dos magistrados ${ }^{73}$. Nesse sentido, também como efeito de sua ocupação e formação letrada de negociante e seu empenho na imprensa pela construção de um espaço cívico como marca da nova ordem, João Soares Lisboa visualizava a vigilância do poder enquanto atribuição fundamental da participação política dos cidadãos e, logo, a definição do mérito como virtude cívica. O redator fazia desse um dispositivo que associaria o interesse particular ao público, politizando a virtú contra a corrupção da virtude pública, preocupação característica das correntes de análise do pensamento político moderno sobre a res publica (FONSECA, 2016, p. 14-15).

Essa associação entre virtude pública e a ampliação do espaço de atuação dos cidadãos na vida pública, inclusive, no que Soares Lisboa defende como uma justiça cidadã, era um fundamento do republicanismo cívico que foi apropriado pelos liberais, tais como frei Caneca e Cipriano Barata, disseminado na Corte nas edições de 1823 do Correio do Rio de Janeiro (FERREIRA, 2017, p. 286-312; FONSECA, 2016, p. 227-284). Nesse sentido, Silvia Carla Pereira de Brito Fonseca (2016) retoma o debate sobre os princípios republicanos, historicizando os discursos e a linguagem republicana de modo a sinalizar suas heranças em um momento de conformação de uma "esfera pública", relacionada com a expansão da imprensa e de sociabilidades que se desenvolveram em "[...] mecanismos informais de participação política" (FONSECA, 2016, p. 13). Na definição de elementos fundamentais do conceito de República: um regime de governo eletivo e temporário, com a primazia do bem comum e a noção de império da lei, a autora identifica, na primeira metade do século XIX no

\footnotetext{
${ }^{72}$ Correio Extraordinário do Rio de Janeiro, n. 9, 26 jul. 1823. p. 41. Hemeroteca Digital da Biblioteca Nacional (Rio de Janeiro). Disponível em: http://bndigital.bn.gov.br Acesso em: 28 ago. 2021.

${ }^{73}$ Correio Extraordinário do Rio de Janeiro, n. 9, 26 jul. 1823. p. 41. Hemeroteca Digital da Biblioteca Nacional (Rio de Janeiro). Disponível em: http://bndigital.bn.gov.br Acesso em: 28 ago. 2021.
} 
Outros Tempos, vol. 19, n. 33, 2022, p. 193-229. ISSN: 1808-8031

Brasil, uma espécie de herança dos discursos republicanos na defesa da precedência da coisa pública e do bem comum, dissociada de uma forma de governo específica, mas convergindo com a tendência liberal pela monarquia constitucional e, como afirma Xavier Guerra, tributário da tradição do humanismo cívico (FONSECA, 2016, p. 12-15; 22-23).

A terceira e quarta acusações versavam sobre o seu suposto “[...] criminoso procedimento em Buenos Aires"74, acusado de retornar ilegalmente para o Rio de Janeiro e por continuar a "[...] escrever doutrina subversiva" na republicação do Correio $^{75}$. De acordo com João Soares Lisboa, o cônsul do Brasil em Buenos Aires, Correia da Câmara, "sem caráter", mentiu em seu depoimento. O redator contrariava seu testemunho dizendo que José Rodrigues Braga, quem lhe recebeu em Buenos Aires, não era "inimigo do Império", inclusive, contava que ele hospedou o cônsul que lhe "pagou" com "negra calúnia e mais negra ingratidão". Ademais, o redator do Correio reproduzia a imagem do cônsul que depois foi registrada nas notas à devassa publicadas no Processo dos Cidadãos e perpetuadas na literatura historiográfica, por exemplo, em Carlos Rizzini (1988). Ele era descrito como um lunático, com desconfianças fantasiosas, que Soares Lisboa, ironicamente, atribuía ao "péssimo caráter" e à "grave moléstia de cérebro" do cônsul" ${ }^{76}$ (FERREIRA, 2017, p. 286344).

Sobre o termo firmado em 1822 de exílio e encerramento da publicação do Correio, Soares Lisboa defendia-se dizendo que recebeu pessoalmente do imperador licença para que retornasse ao Rio de Janeiro e voltasse a publicar o periódico. Afirmava que foi isso que entendeu de sua conversa com D. Pedro depois de ter assinado esse documento, quando o imperador lhe recomendou que cumprisse a ordem: "Nada lhe custa fazer uma pequena viagem"77 e finalizou "Vá, e volte, e continue a escrever"78. Essa afirmação foi lida na época, por exemplo, pelo barão de Mareschal, Agente Diplomático da Áustria no Brasil, como indício do comprometimento de D. Pedro I com o grupo em torno de Joaquim Gonçalves Ledo. Também demonstra que o exílio funcionava como um mecanismo da política liberal, capaz de apaziguar as tensões e de criar um espaço para reorganização das forças políticas,

\footnotetext{
${ }^{74}$ Correio Extraordinário do Rio de Janeiro, n. 8, 24 jul. 1823. p. 36. Hemeroteca Digital da Biblioteca Nacional (Rio de Janeiro). Disponível em: http://bndigital.bn.gov.br Acesso em: 28 ago. 2021.

${ }^{75}$ Correio Extraordinário do Rio de Janeiro, n. 8, 24 jul. 1823. p. 36. Hemeroteca Digital da Biblioteca Nacional (Rio de Janeiro). Disponível em: http://bndigital.bn.gov.br Acesso em: 28 ago. 2021.

${ }^{76}$ Correio Extraordinário do Rio de Janeiro, n. 8, 24 jul. 1823. p. 36. Hemeroteca Digital da Biblioteca Nacional (Rio de Janeiro). Disponível em: http://bndigital.bn.gov.br/ Acesso em: 28 ago. 2021.

${ }^{77}$ Correio Extraordinário do Rio de Janeiro, n. 8, 24 jul. 1823. p. 37. Hemeroteca Digital da Biblioteca Nacional (Rio de Janeiro). Disponível em: http://bndigital.bn.gov.br/ Acesso em: 28 ago. 2021.

${ }^{78}$ Correio Extraordinário do Rio de Janeiro, n. 8, 24 jul. 1823. p. 37. Hemeroteca Digital da Biblioteca Nacional (Rio de Janeiro). Disponível em: http://bndigital.bn.gov.br/ Acesso em: 28 ago. 2021.
} 
Outros Tempos, vol. 19, n. 33, 2022, p. 193-229. ISSN: 1808-8031

apropriado, por exemplo, para garantir o retorno do antigo redator do Correio ao Rio de Janeiro e a reedição desse jornal. No processo não houve qualquer menção ao nome ou a essa conversa com o imperador, sua figura era intocável e não poderia ser envolvida como um simples ator que articulava as alianças políticas. Contudo, na imprensa, a participação de D. Pedro I servia para a defesa de Soares Lisboa, a quem ele recorria desde 1822 na organização da Representação do Povo do Rio de Janeiro e, em 1823, para reafirmar sua crença na relação franca entre cidadãos e o rei na monarquia constitucional (FERREIRA, 2017, p. 137-186).

O quarto ponto no qual se baseava a condenação de Soares Lisboa era relativo à carta que escreveu de Buenos Aires para Joaquim Rodrigues da Costa Simões, alferes do Batalhão de Caçadores, na Colônia de Sacramento. Levada às mãos de José Bonifácio de Andrada pelo cônsul Correia da Câmara, arrolada como prova crime de sua condenação, a primeira providência de Soares Lisboa foi tornar público o seu conteúdo, divulgando-a na íntegra no Correio do Rio de Janeiro e adicionando notas explicativas, dispositivo amplamente utilizado nas publicações periódicas do período. Na devassa também confirmava o envio dela e considerava que nela não apresentava nenhum crime ${ }^{79}$. No Correio do Rio de Janeiro, justificava-se de alguns pontos do conteúdo da carta, que foram considerados como provas de sua reputação republicana e de seu envolvimento na organização de uma revolta contra o governo da Corte fluminense e o imperador.

Com essa publicação, João Soares Lisboa disseminava outra versão sobre o documento que era conhecido do público desde 25 de março de 1823, quando $O$ Espelho a publicou. Em $O$ Espelho, o correspondente contestava a informação trazida pelo "assaz maldito João Soares Lisboa, de que foi chamado pelo imperador para retornar ao Rio de Janeiro". O correspondente defendia que isso era uma invenção para encobrir o rompimento de Soares Lisboa com Joaquim Gonçalves Ledo no exílio, que era "mais constitucional Democrata" que Soares Lisboa, o qual, por sua vez, era visto como "Republicano" na Corte.

Na carta enviada para Costa Simões, João Soares Lisboa criticava a atitude de D. Pedro na sua coroação como imperador do Brasil por ter jurado defender a Coroa "que os Brasileiros lhe acabavam de pôr na Cabeça" e não "[...] a Constituição [que] se fosse digna do Brasil, e dele!" 80 , dando a entender que era compromissado mais com o seu reinado do que com a sua constitucionalidade: "Quer dizer que se lhe não agradar a Constituição, mandaria

\footnotetext{
79 Correio Extraordinário do Rio de Janeiro, n. 8, 24 jul. 1823. p. 37-38. Hemeroteca Digital da Biblioteca Nacional (Rio de Janeiro). Disponível em: http://bndigital.bn.gov.br/ Acesso em: 28 ago. 2021.

${ }^{80}$ Correio Extraordinário do Rio de Janeiro, n. 8, 24 jul. 1823. p. 38. Hemeroteca Digital da Biblioteca Nacional (Rio de Janeiro). Disponível em: http://bndigital.bn.gov.br/ Acesso em: 28 ago. 2021.
} 
Outros Tempos, vol. 19, n. 33, 2022, p. 193-229. ISSN: 1808-8031

fuzilar os que a fizerem!!!"81. Esse era um dos pontos mais polêmicos da carta, sendo interpretado como um desrespeito à dignidade do imperador e visto como um argumento utilizado por ele para instigar a revolta contra D. Pedro e seu governo. Já na carta publicada no Correio do Rio de Janeiro, Soares Lisboa adicionava uma nota ao trecho, admitindo que se excedeu, em uma tentativa de apaziguar sua clara indignação enviada a Costa Simões.

Além disso, justificava que a carta era enviada em uma comunicação particular, escrita com "franqueza e amizade" e sem a intenção de tornar seu conteúdo público, ao publicá-la ou compartilhá-la com outros, demonstrando que sabia o potencial revolucionário, a importância e a gravidade de criticar publicamente o ministério ${ }^{82}$. Em contrapartida, destacava sua constância de opinião, inclusive em relação a sua confiança nos deputados do Brasil e no imperador. Relacionava isso com sua inteireza de caráter e, por isso, suas suposições podiam ser consideradas "temerárias", mas não "criminosas". Moralizava a sua atuação política, baseada na "justiça", "razão" e "legalidade" e oposta ao "maquiavelismo"83, visto com desaprovação e que atribuía, por exemplo, à armação de José Bonifácio de Andrada na sua demissão do dia 30 de outubro e abertura da devassa ${ }^{84}$.

$\mathrm{Na}$ transcrição da sua carta, afirmava que Joaquim Gonçalves Ledo, José Clemente, padre Januário da Cunha Barbosa e ele eram "Constitucionais", mas "os servis" lhe acusavam "o crime de Republicanos". Em nota, Soares Lisboa dizia que só os "Togados" acreditavam na versão dos "servis" e responsabilizava os Andradas pela "maquinação" contra o governo, o que era de conhecimento público e de D. Pedro ${ }^{85}$. Assim, defendia-se afirmando que os "Togados" inverteram "[...] seus discursos a seu bel prazer" 86 para culparem-no de instigar uma revolta contra o governo de D. Pedro: "Miseráveis! Desprezam toda a Lógica, toda a Hermenêutica, e só não perdem de vista seu egoísmo e rancor" ${ }^{\text {" }}$. O redator do Correio considerava que na monarquia constitucional os soldados não são mais "Vassalos", mas sim

\footnotetext{
${ }^{81}$ Correio Extraordinário do Rio de Janeiro, n. 8, 24 jul. 1823. p. 38.Hemeroteca Digital da Biblioteca Nacional (Rio de Janeiro). Disponível em: http://bndigital.bn.gov.br/ Acesso em: 28 ago. 2021.

${ }^{82}$ Correio Extraordinário do Rio de Janeiro, n. 8, 24 jul. 1823. p. 38. Hemeroteca Digital da Biblioteca Nacional (Rio de Janeiro). Disponível em: http://bndigital.bn.gov.br/ Acesso em: 28 ago. 2021.

${ }^{83}$ Michel Foucault ao se debruçar sobre a "[...] literatura antiMaquiavel" nos dá noção do rigor e profundidade da crítica produzida pela adjetivação de "maquiavélico" ao ato e princípio político, de acordo com a cultura política da época. Ao mesmo tempo, destaca que a negação do "espelho" do príncipe escrito por Maquiavel representava uma determinada "[...] boa forma de governar" (FOUCAULT; MACHADO, 2004, p. 279).

${ }^{84}$ Correio Extraordinário do Rio de Janeiro, n. 8, 24 jul. 1823. p. 38. Hemeroteca Digital da Biblioteca Nacional (Rio de Janeiro). Disponível em: http://bndigital.bn.gov.br/ Acesso em: 28 ago. 2021.

${ }^{85}$ Correio Extraordinário do Rio de Janeiro, n. 8, 24 jul. 1823. p. 38. Hemeroteca Digital da Biblioteca Nacional (Rio de Janeiro). Disponível em: http://bndigital.bn.gov.br/ Acesso em: 28 ago. 2021.

${ }^{86}$ Correio Extraordinário do Rio de Janeiro, n. 9, 26 jul. 1823. p. 39-40. Hemeroteca Digital da Biblioteca Nacional (Rio de Janeiro). Disponível em: http://bndigital.bn.gov.br/ Acesso em: 28 ago. 2021.

87 Correio Extraordinário do Rio de Janeiro, n. 9, 26 jul. 1823. p. 39-40. Hemeroteca Digital da Biblioteca Nacional (Rio de Janeiro). Disponível em: http://bndigital.bn.gov.br/ Acesso em: 28 ago. 2021.
} 
Outros Tempos, vol. 19, n. 33, 2022, p. 193-229. ISSN: 1808-8031

comprometidos com ela, "sinônimo de Cidadão" e, por isso, podiam participar da política em defesa desse princípio. Nessa perspectiva, se aproximava da ideia de cidadania armada amplamente disseminada nas recém-independentes repúblicas hispano-americanas (SABATO, 1999; 2009; 2021), bem como, defendida por homens como Cipriano Barata e frei Caneca (BERNARDES, 2006; FONSECA, 2016; MOREL, 1986). Era essa a sua opinião e, se fosse “errada”, os "[...] erros de entendimento não são crimes, salvo no juízo dos Srs. Togados"88. Assim, ao contestar esses pontos sobre sua condenação, João Soares Lisboa a atribuía unicamente à indisposição dos "Srs. Togados" com os princípios dos "direitos dos homens", que foram publicados em sua defesa pública no Correio Extraordinário do Rio de Janeiro de 24 de maio, também enviado aos deputados do Brasil ${ }^{89}$.

\section{A contestação pública da condenação na bonifácia}

Ainda que a defesa de João Soares Lisboa apresentasse clara semelhança com a dos outros réus da bonifácia, notam-se particularidades que diferenciavam sua argumentação daquela publicada posteriormente no Processo dos Cidadãos (1824), como a que atribuía sentido à relação Justiça e Política. Os pontos específicos de sua defesa pública nas publicações do Correio do Rio de Janeiro, como a contestação da imparcialidade e dos procedimentos dos magistrados na devassa, não foram discutidos por autores como Varnhagen e Mello Moraes, até mesmo porque eram apresentados elementos que poderiam contestar a legitimidade do processo e de sua sentença, colocando em dúvida a absolvição ou a reputação dos outros réus da bonifácia (FERREIRA, 2014; 2017, p. 1-29; OLIVEIRA, 1999, p. 296-297; SCHIAVINATTO; FERREIRA, 2014a).

Antes de tudo, o redator mostrava-se indignado com a sua condenação pelo simples fato de que a absolvição de todos os outros réus, para ele, produzia uma contradição: se todos os que organizaram com ele um "conluio republicano" não o fizeram, isso provava que esse movimento nunca existiu. Dessa maneira, concluía que era punido pelo "crime suposto" presente na carta trazida pelo cônsul de Buenos Aires que, ironicamente, Soares Lisboa considerava que "só em um Divã” deveria ser discutido, justificando, no máximo, uma culpa de consciência pelo envio da carta. Além disso, admitia que a acusação de "doutrina

\footnotetext{
${ }^{88}$ Correio Extraordinário do Rio de Janeiro, n. 9, 26 jul. 1823. p. 40. Hemeroteca Digital da Biblioteca Nacional (Rio de Janeiro). Disponível em: http://bndigital.bn.gov.br/ Acesso em: 28 ago. 2021.

${ }^{89}$ Correio Extraordinário do Rio de Janeiro, n. 9, 26 jul. 1823. p. 42. Hemeroteca Digital da Biblioteca Nacional (Rio de Janeiro). Disponível em: http://bndigital.bn.gov.br/ Acesso em: 28 ago. 2021.
} 
Outros Tempos, vol. 19, n. 33, 2022, p. 193-229. ISSN: 1808-8031

subversiva" do Correio do Rio de Janeiro, "[...] como inculcam os Srs. Togados" ser julgada no "Tribunal de Jurados", sendo "[...] todo o julgado em Tribunal incompetente" 91 , reafirmando a defesa do julgamento por júri popular e sua desconfiança em relação aos magistrados ${ }^{92}$.

Diante de sua análise, atribuía a absolvição dos outros réus à diferença de tratamento dada a ele pelos magistrados, pois não possuía "padrinho", nem gozava da proteção de figuras importantes. Automaticamente, insinuava que foi graças a isso que os outros réus foram absolvidos. Dessa maneira, ele mesmo se diferenciava dos outros pela busca de recursos legais e próprios dos meios da monarquia constitucional, recorrendo ao imperador, aos deputados do Brasil e ao público pela imprensa. Ademais, reforçava a imagem dos magistrados como autoridades ligadas aos princípios do Antigo Regime, os quais o nascimento determinava a qualidade dos súditos, em contraposição ao "novo tempo" em que importava mais o mérito e a utilidade do cidadão. Usava esses canais da monarquia constitucional para se defender contra o favorecimento, o "despotismo Togal" e a "injustiça", como a "Patronagem" e a falta de procedimento e transparência dos magistrados:

[...] nós nunca vimos nosso processo, e ignoramos a acusação que nos fizeram falsas testemunhas; não produzimos a defesa; nosso Curador não inquiriu de nós coisa alguma; nunca o vimos, nem conhecemos; e verificou-se em nós o rifão 'Quem não tem padrinho morre Mouro'.

Esqueceram-se mais, que ainda nos restava o recurso à Soberana Assembleia, quando Sua Majestade Imperial, unicamente por mal aconselhado, não nos deferisse com justiça. Esqueceram-se sobretudo, de que o seu preponderante despotismo Togal não pode durar dez meses, quanto mais dez anos, e que nós havíamos gritar incessantemente Justiça! Justiça! Justiça! ${ }^{93}$

Assim, pelo Correio do Rio de Janeiro, João Soares Lisboa tornava pública a defesa formal apresentada por seu advogado diante dos magistrados. Argumentava com as "nulidades", a arbitrariedade da abertura do processo por uma portaria que era ilegal, a falta de procedimentos nos inquéritos às testemunhas, até o desaparecimento intencional do testemunho de algumas delas e a falta de qualquer "corpo de delito" sobre a organização de um "conluio republicano" contra o governo e o imperador. Destaca-se que foi nas publicações do Correio do Rio de Janeiro que se atribuiu a isso intencionalidade política, associando os

\footnotetext{
${ }^{90}$ Correio Extraordinário do Rio de Janeiro, n. 9, 26 jul. 1823. p. 42. Hemeroteca Digital da Biblioteca Nacional (Rio de Janeiro). Disponível em: http://bndigital.bn.gov.br/ Acesso em: 28 ago. 2021.

${ }^{91}$ Correio Extraordinário do Rio de Janeiro, n. 9, 26 jul. 1823. p. 42. Hemeroteca Digital da Biblioteca Nacional (Rio de Janeiro). Disponível em: http://bndigital.bn.gov.br/ Acesso em: 28 ago. 2021.

${ }^{92}$ Correio Extraordinário do Rio de Janeiro, n. 9, 26 jul. 1823. p. 42. Hemeroteca Digital da Biblioteca Nacional (Rio de Janeiro). Disponível em: http://bndigital.bn.gov.br/ Acesso em: 28 ago. 2021.

${ }^{93}$ Correio Extraordinário do Rio de Janeiro, n. 3, 12 jul. 1823. p. 13-14. Hemeroteca Digital da Biblioteca Nacional (Rio de Janeiro). Disponível em: http://bndigital.bn.gov.br/ Acesso em: 28 ago. 2021.
} 
Outros Tempos, vol. 19, n. 33, 2022, p. 193-229. ISSN: 1808-8031

“despotismos” de José Bonifácio de Andrada e a vitimização dos réus da bonifácia ao que ele chamou de "Despotismo Togal". Esse conteúdo reapareceu nas notas ao inquérito e na apresentação publicada sob o nome de Processo dos Cidadãos em 1824, porém, de modo menos agressivo (FERREIRA, 2017, p. 253-285; SCHIAVINATTO; FERREIRA, 2014a, 2014b, 2014c).

Nas publicações do Correio do Rio de Janeiro de 1823, para dar significado ao "Despotismo Togal" e argumentar contra a sua condenação, o redator retomava o imaginário liberal do início do século XIX, também presente nas edições do ano anterior do periódico. Enxergava com desconfiança os magistrados, vistos como homens apegados aos "privilégios" da velha ordem e resistentes à delimitação de seus poderes pelas normas constitucionais. De modo semelhante à visão do vintismo, os magistrados eram vistos como instrumentos dedicados ao funcionamento do despotismo, conduzidos pela alta magistratura e juízes escolhidos pelo rei, acostumados a oprimirem os povos (BRIGOLA, 1990, p. 98). Para Soares Lisboa, os magistrados deveriam ser submetidos à observância da lei para garantia do exercício da constitucionalidade (FERREIRA, 2017, p. 282-285).

Apenas na imprensa João Soares Lisboa poderia utilizar "Despotismo Togal". Esse termo era muito agressivo e impactante, mas de grande valia ao demarcar seu posicionamento liberal na arena pública. $\mathrm{O}$ mesmo não tinha nenhuma validade jurídica e seria considerado desacato se proferido diante dos "Srs. Togados"94. Ele lamentava: "Corpo Monstruoso! Que vergonheira! Ah! Se os Meritíssimos pudessem reformar os Autos, os seus Acordão" "95. Para ele, a "[...] nulidade da falta do corpo de delito"96 declarada na abertura da devassa revelava o desejo dos magistrados de condenar por vontade própria ou de "pessoas interessadas e influentes" e não baseados na lei a quem deveriam obedecer ${ }^{97}$. Esse tipo de contestação se repetiu nas publicações do Correio do Rio de Janeiro ao longo de 1823, questionando os procedimentos e a moralidade dos magistrados de forma agressiva:

Os 14 Demagogos do ano passado foram julgados inocentes, e se acham livres de culpa e pena, menos o Redator do Correio que estas linhas escrevem!!! E então os Meritíssimos são, ou não são Ladrões piores que salteadores de estrada? Roubaramnos a liberdade e a justiça, ou não? Como escaparem-se deste labirinto? Os criminosos eram 14, o Redator do Correio, João Soares Lisboa, era o sexto na

\footnotetext{
${ }^{94}$ Correio do Rio de Janeiro, n. 4, 5 ago. 1823. p. 13. Hemeroteca Digital da Biblioteca Nacional (Rio de Janeiro). Disponível em: http://bndigital.bn.gov.br/ Acesso em: 28 ago. 2021.

95 Correio do Rio de Janeiro, n. 48, 27 set. 1823. p. 192. Hemeroteca Digital da Biblioteca Nacional (Rio de Janeiro). Disponível em: http://bndigital.bn.gov.br/ Acesso em: 28 ago. 2021.

${ }^{96}$ Correio Extraordinário do Rio de Janeiro, n. 9, 26 jul. 1823. p. 42. Hemeroteca Digital da Biblioteca Nacional (Rio de Janeiro). Disponível em: http://bndigital.bn.gov.br/ Acesso em: 28 ago. 2021.

${ }^{97}$ Correio Extraordinário do Rio de Janeiro, n. 9, 26 jul. 1823. p. 42. Hemeroteca Digital da Biblioteca Nacional (Rio de Janeiro). Disponível em: http://bndigital.bn.gov.br/ Acesso em: 28 ago. 2021.
} 
Outros Tempos, vol. 19, n. 33, 2022, p. 193-229. ISSN: 1808-8031

escala; os oito que se lhe seguiam estavam inocentes, os cinco primeiros também, como Diabo se arranjou o negócio de maneira que o Processo, e tudo quanto nele se inserta fez crime, e grande crime a um só? Assim se julga da Liberdade e vida dos Cidadãos? Ou os Juízes foram comprados a favor dos outros e são Réus por se deixarem subornar, ou julgaram com escandalosa parcialidade e são Réus por infringirem pena sobre quem não tinha crime!!! Iremos fazendo uso de nosso sangue frio, até que chegue o momento de justar-nos contas; a época não está distante, salvo se o Anjo mal soprar a discórdia sobre esta ditosa Plaga, o que Deus não há de permitir $^{98}$.

Outra informação registrada exclusivamente no Correio do Rio de Janeiro e que se desvaneceu na literatura histórica, era que, dentre os magistrados que julgaram a bonifácia, o redator Soares Lisboa recebeu dois votos para sua absolvição. Explicava que confiava na competência de seu advogado de defesa, Joaquim Gaspar de Almeida, o mesmo de todos os outros réus, mas pedia a revisão de sua sentença, o que demorava a ser aprovado ${ }^{99}$. Sobre isso, afirmava que os "meritissimos" tinham "medo" de permiti-la "por causa da manifesta injustiça", que seria observada caso os catorze novos desembargadores analisassem o processo. No fim de suas reflexões, com ironia, Soares Lisboa revelava que a publicação do Processo dos Cidadãos (1824) era prevista desde 1823, mas que imaginava que essa versão da devassa seria censurada pelos "Togados", que tentariam "decretar a extinção das Tipografias para não aparecer em letras de forma o monstruoso Processo com suas competentes notas! Há de ser peça digna de Museu!"100. Isso elucida a semelhança de argumentos e elementos entre os apresentados em sua defesa pública no Correio do Rio de Janeiro em 1823 e as notas que comentavam o inquérito da bonifácia e vieram a público sob o título de Processo dos Cidadãos (1824).

Os deputados não intercederam pela inocência de João Soares Lisboa e, em 29 de julho de 1823, a resolução sobre a revisão de sua sentença definia que os dez anos de prisão e o pagamento de cem mil réis das custas do processo eram reduzidos a oito anos de exílio do Brasil e em cinquenta mil réis (SCHIAVINATTO; FERREIRA, 2014b, p. 345-346). À primeira vista, estabelecia-se uma pena menos rigorosa, contudo, essa não era a opinião de Soares Lisboa, que protestou veemente no Correio do Rio de Janeiro: “O mais gracioso deste drama é, que reformando-se o respeitadíssimo Acordão, ficou a emenda pior que o soneto, em lugar de 10 anos de prisão segura (que não caia) foi a reforma 8 anos de extermínio!!! [...]”.

\footnotetext{
${ }^{98}$ Correio do Rio de Janeiro, n. 60, 11 out. 1823. p. 240. Hemeroteca Digital da Biblioteca Nacional (Rio de Janeiro). Disponível em: http://bndigital.bn.gov.br/ Acesso em: 28 ago. 2021.

${ }^{99}$ Correio Extraordinário do Rio de Janeiro, n. 9, 26 jul. 1823. p. 42. Hemeroteca Digital da Biblioteca Nacional (Rio de Janeiro). Disponível em: http://bndigital.bn.gov.br/ Acesso em: 28 ago. 2021.

${ }^{100}$ Correio do Rio de Janeiro, n. 48, 27 set. 1823. p. 192. Hemeroteca Digital da Biblioteca Nacional (Rio de Janeiro). Disponível em: http://bndigital.bn.gov.br/ Acesso em: 28 ago. 2021.
} 
Outros Tempos, vol. 19, n. 33, 2022, p. 193-229. ISSN: 1808-8031

Afirmava que isso o "obrigava" a "[...] aprontar biscoito para a viagem"101: “[...] santa paciência, iremos pregar a outra freguesia onde os ouvintes tenham o tímpano mais apto para receber nossa desentoada voz; não perdemos de todo a esperança de encontrarmos quem ache melodioso nosso eco"102. Apesar da ordem de exílio e autorização de passaporte para a Inglaterra, Soares Lisboa encontrou quem lesse e ouvisse suas ideias em Recife, onde aderiu a Confederação do Equador, publicou o Desengano aos Brasileiros e morreu em combate contra as tropas imperiais no Couro D’Anta, em 1824.

No retorno do exílio em Buenos Aires, João Soares Lisboa não contava que a rearticulação do jogo político depois de instalada a Assembleia Legislativa e do retorno de Joaquim Gonçalves Ledo do exílio criassem novos obstáculos à sua ascensão a círculos de poder da Corte, ocupado por seus antigos aliados, agora comprometidos com um projeto de constituição que não se conciliava com o idealizado por Soares Lisboa. Ao longo de suas trajetórias, Joaquim Gonçalves Ledo, o padre Januário da Cunha Barbosa e José Clemente Pereira negociaram com o imperador, magistrados, com as Câmaras e o ministro José Bonifácio de Andrada pela via institucional, viajando ao encontro dos "homens bons" das localidades de Minas Gerais e São Paulo, ou ocupando cargos como o de procurador da província do Rio de Janeiro, no caso de Joaquim Gonçalves Ledo. Por seu turno, João Soares Lisboa apostava na negociação aberta e direta com D. Pedro enquanto príncipe regente e depois imperador e, pela imprensa, aos olhos dos leitores. Essa maneira teve êxito até a sua condenação na bonifácia, apesar e por conta desse fracasso, na Corte estava isolado dos círculos de poder.

\section{Considerações finais}

No retorno do exílio em Buenos Aires, João Soares Lisboa, encarcerado, utilizava a imprensa e o apelo aos deputados para sua absolvição na bonifácia. Em um contexto de inexistência de um poder judiciário organizado, ele se sustentava e disseminava uma imagem pejorativa dos magistrados que era preeminente na cultura política liberal da América, por exemplo, definindo a expressão "Despotismo Togal". Somava-se à concepção da justiça, moral, virtude e mérito particular que defendia, a ampliação da participação cidadã no governo, fosse uma república ou monarquia constitucional, ambas baseadas na soberania

\footnotetext{
${ }^{101}$ Correio do Rio de Janeiro, n. 10, 12 ago. 1823. p. 39-40. Hemeroteca Digital da Biblioteca Nacional (Rio de Janeiro). Disponível em: http://bndigital.bn.gov.br/ Acesso em: 28 ago. 2021.

102 Correio do Rio de Janeiro, n. 10, 12 ago. 1823. p. 39-40. Hemeroteca Digital da Biblioteca Nacional (Rio de Janeiro). Disponível em: http://bndigital.bn.gov.br/ Acesso em: 28 ago. 2021.
} 
Outros Tempos, vol. 19, n. 33, 2022, p. 193-229. ISSN: 1808-8031

popular. Nesse sentido, valorizava o julgamento de devassas políticas por cidadãos que formariam o júri popular, da figura dos soldados como cidadãos armados e de procedimentos legais no controle da Justiça. A relação entre Política e Justiça repercutiu também na construção da sua memória e dos outros réus da bonifácia de diferentes maneiras, sobretudo, na publicação da devassa comentada no Correio do Rio de Janeiro e do Processo dos Cidadãos (1824).

Esse exame das publicações de João Soares Lisboa permite vislumbrar o domínio e o debate em torno da constituição do judiciário e do longo caminho a percorrer em sua construção no Império do Brasil. Nesse sentido, não se trata de identificar ou não a defesa do regime republicano por João Soares Lisboa nas publicações do Correio do Rio de Janeiro, mas de visualizarmos elementos de discursos republicanos como princípios que norteavam um determinado modo de entender o governo e a cidadania, que se desdobrou na crítica aos "togados" e defesa de uma justiça cidadã que fazia com que as publicações de Soares Lisboa de 1823 fossem lidas como radicais e republicanas pelos seus coevos, tanto para se opor a elas, isolando Soares Lisboa politicamente na Corte - no rompimento com antigos aliados, como Gonçalves Ledo - quanto para prestigiá-lo, caso de frei Caneca e Manoel Carvalho Paes Andrade, que receberam Soares Lisboa em Recife, na Confederação do Equador (1824).

Essa aproximação de Soares Lisboa ao ideário dos líderes da Confederação do Equador também foi motivada pela sua participação nos debates políticos desenvolvidos na arena pública de Buenos Aires quando exilado. A criminalização do seu exílio e a contraposição disso pelo seu entendimento do que viveu, demonstra também a importância do exílio como mecanismo regulador da política liberal (ROGINER; SZNAJDER, 2014), impactando sua memória e trajetória pública e alçando-o, segundo Morel, a “[...] um dos precursores do ideário radical dos liberais Exaltados" (MOREL, 2017, p. 249). A esse respeito, pode-se afirmar que a questão da constituição e organização de um poder judiciário foi eminente e fruto de inúmeras discórdias, alianças e lutas políticas entre os liberais do Período Regencial no Brasil (BASILE, 2004).

\section{Referências}

\section{Documentos}

Correio do Rio de Janeiro, n. 59, 22 jun. 1822. Hemeroteca Digital da Biblioteca Nacional (Rio de Janeiro). Disponível em: http://bndigital.bn.gov.br/ Acesso em: 28 ago. 2021.

Correio do Rio de Janeiro, n. 62, 27 jul. 1822. Hemeroteca Digital da Biblioteca Nacional (Rio de Janeiro). Disponível em: http://bndigital.bn.gov.br/ Acesso em: 28 ago. 2021. 
Outros Tempos, vol. 19, n. 33, 2022, p. 193-229. ISSN: 1808-8031

Correio do Rio de Janeiro, n. 4, 5 ago. 1823. Hemeroteca Digital da Biblioteca Nacional (Rio de Janeiro). Disponível em: http://bndigital.bn.gov.br/ Acesso em: 28 ago. 2021.

Correio do Rio de Janeiro, n. 10, 12 ago. 1823. Hemeroteca Digital da Biblioteca Nacional (Rio de Janeiro). Disponível em: http://bndigital.bn.gov.br/ Acesso em: 28 ago. 2021.

Correio do Rio de Janeiro, n. 48, 27 set. 1823. Hemeroteca Digital da Biblioteca Nacional (Rio de Janeiro). Disponível em: http://bndigital.bn.gov.br/ Acesso em: 28 ago. 2021.

Correio do Rio de Janeiro, n. 60, 11 out. 1823. Hemeroteca Digital da Biblioteca Nacional (Rio de Janeiro). Disponível em: http://bndigital.bn.gov.br/ Acesso em: 28 ago. 2021.

Correio do Rio de Janeiro, n. 92, 19 nov. 1823. Hemeroteca Digital da Biblioteca Nacional (Rio de Janeiro). Disponível em: http://bndigital.bn.gov.br/ Acesso em: 28 ago. 2021.

Correio Extraordinário do Rio de Janeiro, n. 1, 24 maio 1823. Hemeroteca Digital da Biblioteca Nacional (Rio de Janeiro). Disponível em: http://bndigital.bn.gov.br/ Acesso em: 28 ago. 2021.

Correio Extraordinário do Rio de Janeiro, n. 3, 12 jul. 1823. Hemeroteca Digital da Biblioteca Nacional (Rio de Janeiro). Disponível em: http://bndigital.bn.gov.br/ Acesso em: 28 ago. 2021.

Correio Extraordinário do Rio de Janeiro, n. 5, 19 jul. 1823. Hemeroteca Digital da Biblioteca Nacional (Rio de Janeiro). Disponível em: http://bndigital.bn.gov.br/ Acesso em: 28 ago. 2021.

Correio Extraordinário do Rio de Janeiro, n. 7, 23 jul. 1823. Hemeroteca Digital da Biblioteca Nacional (Rio de Janeiro). Disponível em: http://hemerotecadigital.bn.br. Acesso em: 28 ago. 2021.

Correio Extraordinário do Rio de Janeiro, n. 8, 24 jul. 1823. Hemeroteca Digital da Biblioteca Nacional (Rio de Janeiro). Disponível em: http://bndigital.bn.gov.br/ Acesso em: 28 ago. 2021.

Correio Extraordinário do Rio de Janeiro, n. 9, 26 jul. 1823. Hemeroteca Digital da Biblioteca Nacional (Rio de Janeiro). Disponível em: http://bndigital.bn.gov.br/ Acesso em: 28 ago. 2021.

DIÁRIO da Assembleia Geral Constituinte e Legislativa do Império do Brasil, 1823. Brasília, DF: Senado Federal, 2003.

Diário do Governo do Rio de Janeiro, n. 40, 19 fev. 1823. Hemeroteca Digital da Biblioteca Nacional (Rio de Janeiro). Disponível em: http://bndigital.bn.gov.br/ Acesso em: 28 ago. 2021.

Diário do Governo do Rio de Janeiro, n. 43, 22 fev. 1823. Hemeroteca Digital da Biblioteca Nacional (Rio de Janeiro). Disponível em: http://bndigital.bn.gov.br/ Acesso em: 28 ago. 2021.

El Correo de las Provincias, n. 11, 27 fev. 1822. Disponível em: https://catalogo.bn.gov.ar Acesso em: 28 ago. 2021. 
Outros Tempos, vol. 19, n. 33, 2022, p. 193-229. ISSN: 1808-8031

El Espíritu de Buenos Aires, n. 4, 6 fev. 1822. Colecciones Digitales. Biblioteca Nacional Mariano Moreno (Buenos Aires). Disponível em: https://catalogo.bn.gov.ar Acesso em: 28 ago. 2021.

El Espíritu de Buenos Aires, n. 5, 9 fev. 1822. Colecciones Digitales. Biblioteca Nacional Mariano Moreno (Buenos Aires). Disponível em: https://catalogo.bn.gov.ar Acesso em: 28 ago. 2021.

El Espíritu de Buenos Aires, n. 14, 13 mar. 1822. Colecciones Digitales. Biblioteca Nacional Mariano Moreno (Buenos Aires). Disponível em: https://catalogo.bn.gov.ar Acesso em: 28 ago. 2021.

El Espíritu de Buenos Aires, n. 16, 20 mar. 1822. Colecciones Digitales. Biblioteca Nacional Mariano Moreno (Buenos Aires). Disponível em: https://catalogo.bn.gov.ar Acesso em: 28 ago. 2021.

El Espíritu de Buenos Aires, n. 17, 23 mar. 1822. Colecciones Digitales. Biblioteca Nacional Mariano Moreno (Buenos Aires). Disponível em: https://catalogo.bn.gov.ar Acesso em: 28 ago. 2021.

El Espíritu de Buenos Aires, n. 19, 4 abr. 1822. Colecciones Digitales. Biblioteca Nacional Mariano Moreno (Buenos Aires). Disponível em: https://catalogo.bn.gov.ar Acesso em: 28 ago. 2021.

El Espíritu de Buenos Aires, n. 26, 13 jun. 1822. Colecciones Digitales. Biblioteca Nacional Mariano Moreno (Buenos Aires). Disponível em: https://catalogo.bn.gov.ar Acesso em: 28 ago. 2021.

El Pacifico Oriental de Montevideo, n. 19, 26 abr. 1822. Colecciones Digitales. Biblioteca Nacional Mariano Moreno (Buenos Aires). Disponível em: https://catalogo.bn.gov.ar Acesso em: 28 ago. 2021.

El Teatro de la Opinión, n. 4, 13 jun. 1823. Colecciones Digitales. Biblioteca Nacional Mariano Moreno (Buenos Aires). Disponível em: https://catalogo.bn.gov.ar Acesso em: 28 ago. 2021.

El Teatro de la Opinión, n. 8, 11 jul. 1823. Colecciones Digitales. Biblioteca Nacional Mariano Moreno (Buenos Aires). Disponível em: https://catalogo.bn.gov.ar Acesso em: 28 ago. 2021.

Legión del Orden ó Voz del Pueblo, n. 10, 12 jan. 1821. Disponível em: https://catalogo.bn.gov.ar Acesso em: 28 ago. 2021.

O Espelho, n. 159, 27 maio 1823. Hemeroteca Digital da Biblioteca Nacional (Rio de Janeiro). Disponível em: http://bndigital.bn.gov.br Acesso em: 28 ago. 2021.

O Espelho, n. 160, 30 maio 1823. Hemeroteca Digital da Biblioteca Nacional (Rio de Janeiro). Disponível em: http://bndigital.bn.gov.br/ Acesso em: 28 ago. 2021.

Revista Ligera de Buenos Aires, n. 1, 1 jan. 1822. Colecciones Digitales. Biblioteca Nacional Mariano Moreno (Buenos Aires). Disponível em: https://catalogo.bn.gov.ar Acesso em: 28 ago. 2021. 
Outros Tempos, vol. 19, n. 33, 2022, p. 193-229. ISSN: 1808-8031

\section{Bibliografia}

BASILE, Marcello Otávio Neri de Campos. O Império em construção: projetos de Brasil e ação política na Corte regencial. 2004. Tese (Doutorado em História Social) - Universidade Federal do Rio de Janeiro, Rio de Janeiro, 2004.

BELTRAN, Oscar R. Historia del Periodismo Argentino: Pensamiento y Obra de los Forjadores de la Patria. Buenos Aires: Editorial Sopena Argentina, 1943.

BERNARDES, Denis Antônio de Mendonça. O patriotismo constitucional: Pernambuco, 1820-1822. Recife: Editora Universitária UFPE, 2006.

BRIGOLA, João Carlos Pires. Ciência e política do pombalismo ao liberalismo: Francisco Simões Margiochi. 1990. Dissertação (Mestrado em História Cultural e Política) Universidade Nova de Lisboa, Lisboa, 1990.

CHUST, Manuel. La Cuestión nacional americana en las Cortes de Cádiz (1810-1814). Valência: Centro Francisco Tomás y Valiente UNED Alzira-Valencia, Fundación Instituto Historia Social, 1999.

DEMURO, Wilson González. La prensa de Montevideo, 1814-1825: imprentas, periódicos y debates públicos en tiempos de revolución. Montevideo: Ediciones Universitarias, Unidad de Comunicación de la Universidad de la República, 2018.

FERNÁNDEZ SEBASTIÁN, Javier. Liberalismo nacientes em el atlântico iberocamericano: "liberal" como concepto y como identidad política, 1750-1850. In: FERNÁNDEZ

SEBASTIÁN, Javier. Diccionario político y social del mundo iberoamericano: La era de las revoluciones, 1750-1850. Madrid: Fundación Carolina, Sociedad Estatal de Conmemoraciones Culturales, Centro de Estudios Políticos y Constitucionales, 2009. v. Iberoconceptos-Ip. p. 695-731.

FERREIRA, Paula Botafogo Caricchio. Redatores no Rio de Janeiro e Deputados nas Cortes de Lisboa pela Construção da Monarquia Constitucional Portuguesa (1821-1822). 2011. Dissertação (Mestrado em História Social) - Universidade de São Paulo, São Paulo, 2011.

FERREIRA, Paula Botafogo Caricchio. O princípio da moderação e a condenação de João Soares Lisboa na bonifácia: a interpretação de Mello Moraes na obra "A Independência e o Império do Brasil”" (1877). In: RIBEIRO, Gladys Sabina; MARTINS, Ismênia de Lima; FERREIRA, Tânia Bessone da Cruz (org.). O oitocentos sobre novas perspectivas. São Paulo: Alameda, 2014. p. 253-274.

FERREIRA, Paula Botafogo Caricchio. Negócios, impressos e política: a trajetória pública de João Soares Lisboa (1800-1824). Tese (Doutorado em História) - Universidade Estadual de Campinas, Campinas, 2017.

FERREIRA, Paula Botafogo Caricchio. Civique de Gastine (1793-1822) no Correio do Rio de Janeiro: Pacto Colonial , Economia Política e as Independências da América. Estudos IberoAmericanos, v. 46, n. 2, p. e35177, 2020a.

FERREIRA, Paula Botafogo Caricchio. A trajetória mercantil de João Soares Lisboa: de "comerciante de Porto Alegre" a negociante de grosso trato na Corte do Rio de Janeiro (1800- 
Outros Tempos, vol. 19, n. 33, 2022, p. 193-229. ISSN: 1808-8031

1818). Revista do Instituto Histórico e Geográfico do Rio Grande do Sul, v. 157, p. 13-39, dez. 2020b.

FERREIRA, Paula Botafogo Caricchio. O exílio liberal no Cone Sul da América de 1820: o caso de João Soares Lisboa em Buenos Aires (1822-1823). Revista Complutense de Historia de América, n. 47, p. 67-88, $2021 \mathrm{a}$.

FERREIRA, Paula Botafogo Caricchio. A imprensa de Montevidéu (1814-1825) como Fonte Histórica. Almanack, n. 28, set. 2021b.

FONSECA, Silvia Carla Pereira de Brito. A ideia de República no Império do Brasil: Rio de Janeiro e Pernambuco (1824-1834). Jundiaí: Paco Editorial, 2016.

FOUCAULT, Michel; MACHADO, Roberto. Governamentalidade. In: FOUCAULT, Michel. Microfísica do poder. Rio de Janeiro: Edições Graal Ltda, 2004. p. 277-293.

GUIMARÃES, Manoel Luiz Salgado. Expondo a história: imagens construindo o passado. Anais do Museu Histórico Nacional, v. 34, p. 13-48, 2002.

GUIMARÃES, Manoel Luiz Salgado. A cultura histórica oitocentista: a constituição de uma memória disciplinar. In: PESAVENTO, Sandra Jatahy (org.). História Cultural Experiências de Pesquisa. Porto Alegre: Ed. UFRGS, 2003. p. 9-24.

HESPANHA, António M. Guiando a mão invisível: direitos, estado e lei no Liberalismo Monárquico Português. São Paulo: Almedina Brasil, 2004.

JANCSÓ, István; PIMENTA, João Paulo G. Peças de um mosaico (ou apontamentos para o estudo da emergência da identidade nacional brasileira). In: MOTA, Carlos Guilherme (org.). Viagem incompleta: a experiência brasileira : 1500-2000. São Paulo: Senac, 2000. p. 127-175.

KOSELLECK, Reinhart. Crítica e crise: uma contribuição à patogênese do mundo burguês. Rio de Janeiro: Contraponto, Ed. UERJ, 1999.

KOSELLECK, Reinhart. Futuro Passado: contribuição à semântica dos tempos históricos. Rio de Janeiro: Contraponto, Ed. PUC Rio, 2006.

KOSELLECK, Reinhart. Estratos do Tempo: Estudos sobre o Tempo. Rio de Janeiro: Contraponto, Ed. PUC Rio, 2014.

LEITE, Renato Lopes. Republicanos e libertários: pensadores radicais no Rio de Janeiro, 1822. Rio de Janeiro: Civilização Brasileira, 2000.

LESCANO, Mariana Paula. La prensa durante el período rivadaviano: El Argos de Buenos Aires (1821-1825). Almanack, n. 9, p. 136-152, 2015.

LUSTOSA, Isabel. Insultos impressos: a guerra dos jornalistas na Independência, 1821-1823. São Paulo: Companhia das Letras, 2000.

MORAES, Alexandre J. de Mello. Brasil histórico. Rio de Janeiro: Typ. de Pinheiro, 1866.

MORAES, Alexandre J. de Mello. A independência e o império do Brasil. Brasília. DF: Edições do Senado Federal, 2004. v. 18. 
Outros Tempos, vol. 19, n. 33, 2022, p. 193-229. ISSN: 1808-8031

MOREL, Marco. Cipriano Barata. São Paulo: Brasiliense, 1986.

MOREL, Marco. As transformações dos espaços públicos: imprensa, atores políticos e sociabilidades na cidade imperial, 1820-1840. São Paulo: Hucitec, 2005.

MOREL, Marco. A Revolução do Haiti e o Brasil escravista: o que não deve ser dito. Jundiaí: Paco Editorial, 2017.

MOREL, Marco; BARROS, Marina Monteiro de. Palavra, imagem e poder: o surgimento da imprensa no Brasil do século XIX. Rio de Janeiro: DP \& A, 2003.

MYERS, Jorge. Identidades porteñas. El discurso ilustrado en torno a la nación y el rol de la prensa: El Argos de Buenos Aires, 1821-1825. In: ALONSO, Paula. (org.). Construcciones impresas, panfletos, diarios y revistas en la formación de los estados nacionales en América Latina. México: FCE, 2004. p. 39-63.

NEVES, Lúcia Maria Bastos Pereira das. Corcundas e constitucionais: a cultura política da independência, 1820-1822. Rio de Janeiro: FAPERJ, 2003.

NUNES, Tassia Toffoli. Liberdade de imprensa no Império brasileiro: os debates parlamentares (1820-1840). 2010. Dissertação (Mestrado em História) - Universidade de São Paulo, São Paulo, 2010.

OLIVAL, Fernanda. As ordens militares e o Estado moderno: honra, mercê e venalidade em Portugal (1641-1789). Lisboa: Estar, 2001.

OLIVEIRA, Cecília Helena de Salles. A astúcia liberal: relações de mercado e projetos políticos no Rio de Janeiro (1820-1824). São Paulo: USF, 1999.

PIMENTA, João Paulo Garrido. A independência do Brasil e a experiência hispanoamericana (1808-1822). São Paulo: Hucitec, FAPESP, 2015.

PIMENTA, João Paulo Garrido. Tempos e espaços das independências: a inserção do Brasil no mundo ocidental (c. 1780-c. 1830). São Paulo: Entr[H]istória, 2017.

RIZZINI, Carlos. O livro, o jornal e a tipografia no Brasil, 1500-1822 (com um breve estudo geral sobre a informação). São Paulo: Imprensa Oficial do Estado, 1988.

RONIGER, Luis; SZNAJDER, Mario. La Política del Destierro y El Exilio en America Latina. México: Fondo de Cultura Económica, 2014. E-book.

SABATO, Hilda. Ciudadania politica y formacion de las naciones: perspectivas historicas de America Latina. México: Fondo de Cultura Económica, 1999.

SABATO, Hilda. Soberania popular, cidadania, e nação na América Hispânica: a experiência republicana do século XIX. Almanack Braziliense, n. 9, p. 5-22, maio 2009.

SABATO, Hilda. Repúblicas del Nuevo Mundo: el experimento político latinoamericano del siglo XIX. Buenos Aires: Taurus, 2021. 
Outros Tempos, vol. 19, n. 33, 2022, p. 193-229. ISSN: 1808-8031

SCHIAVINATTO, Iara Lis; FERREIRA, Paula Botafogo Caricchio. As rememorações da "bonifácia": entre a devassa de 1822 e o processo dos cidadãos de 1824. Revista do IHGB, v. 175, n. 462, p. 201-238, mar. 2014a.

SCHIAVINATTO, Iara Lis; FERREIRA, Paula Botafogo Caricchio. As rememorações da "bonifácia": entre a devassa de 1822 e o Processo dos cidadãos de 1824 - (2a parte). Revista do IHGB, v. 175 , n. 463 , p. 288-347, jun. 2014b.

SCHIAVINATTO, Iara Lis; FERREIRA, Paula Botafogo Caricchio. As rememorações da "bonifácia": entre a devassa de 1822 e o processo dos cidadãos de 1824 - ( $3^{\mathrm{a}}$ parte). Revista do IHGB, v. 175, n. 464, p. 291-348, set. 2014c.

SIFUENTES, Mônica Jacqueline. O Poder Judiciário no Brasil e em Portugal: reflexões e perspectivas. Brasília, ano 36, n. 142, p. 325-340, 1999.

SLEMIAN, Andréa. Vida política em tempo de crise: Rio de Janeiro (1808-1824). São Paulo: Aderaldo \& Rothschild, 2006.

SLEMIAN, Andréa. Sob o império das leis: constituição e unidade nacional na formação do Brasil (1822-1834). São Paulo: Hucitec, FAPESP, 2009.

TERNAVASIO, Marcela. Historia de la Argentina 1806-1852. Buenos Aires: Siglo Veintiuno Editores, 2009.

VARNHAGEN, Francisco Adolfo de. História da independência do Brasil: até ao reconhecimento pela antiga metrópole, compreendendo, separadamente, a dos sucessos ocorridos em algumas províncias até essa data. Brasília, DF: Senado Federal, 2010. v. 137.

VIANNA, Jorge Vinícius Monteiro. Imaginando a nação: o vocabulário político da imprensa fluminense no processo de Independência do Brasil (1821-1824). 2011. [166 f.]. Dissertação (Mestrado em História) - Universidade Federal Rural do Rio de Janeiro, [Seropédica - RJ], 2011.

WINTER, Murillo Dias. Imprensa periódica e a construção da identidade oriental (Província Cisplatina - 1821-1828). Porto Alegre: Editora Fi, 2018. 